Prepared in cooperation with Tulsa County

Estimation of Annual Suspended-Sediment Fluxes, 1931-95, and Evaluation of Geomorphic Changes, 1950-2010, in the Arkansas River near Tulsa, Oklahoma

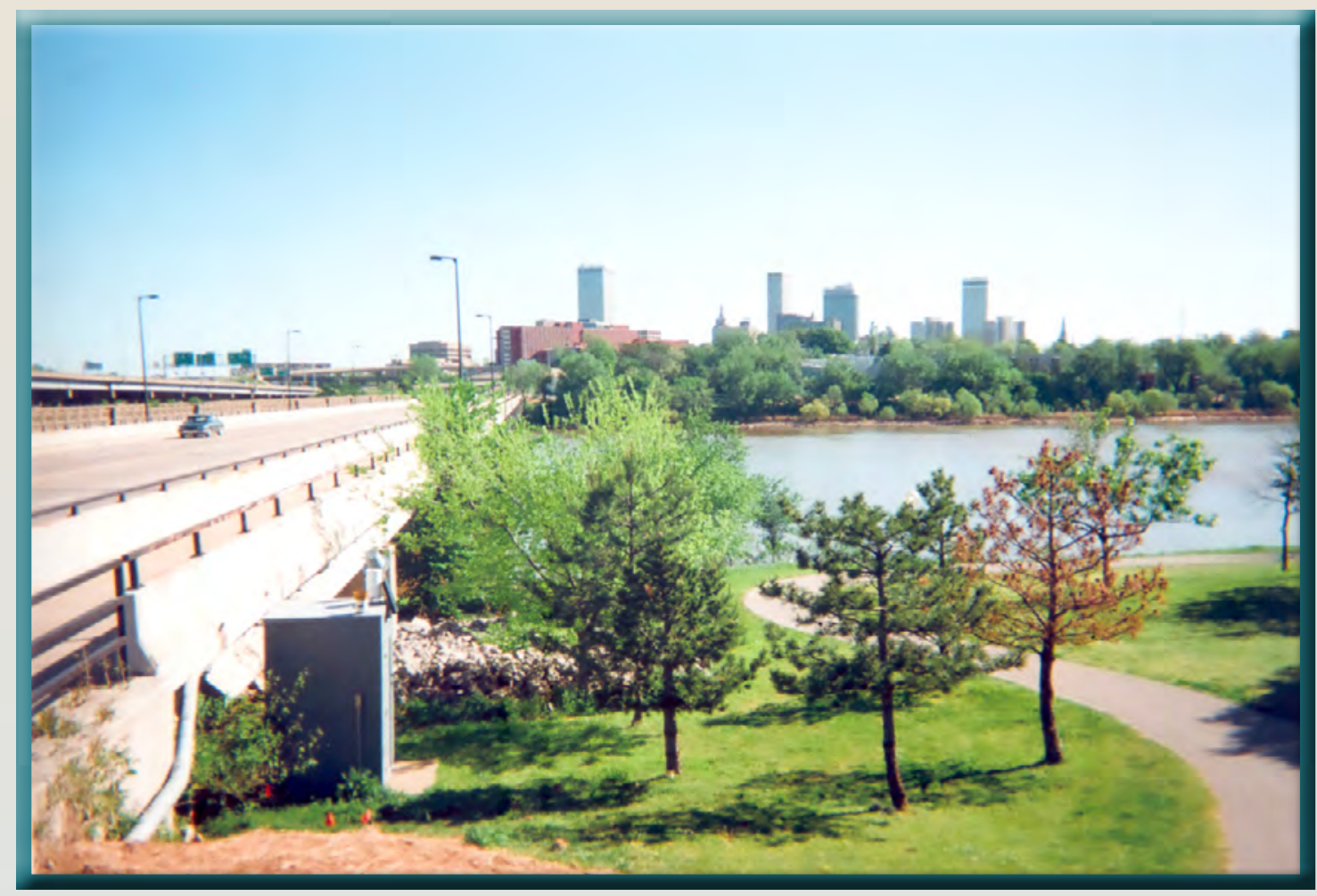

Scientific Investigations Report 2011-5091 
Cover. Arkansas River at Tulsa, Oklahoma, streamflow-gaging station located on the downstream side of the $11^{\text {th }}$ Street bridge over the Arkansas River. Photograph is looking north towards the city of Tulsa. (Photograph by Steven D. Smith, U.S. Geological Survey, 2007). 


\section{Estimation of Annual Suspended-Sediment Fluxes, 1931-95, and Evaluation of Geomorphic Changes, 1950-2010, in the Arkansas River near Tulsa, Oklahoma}

By Jason M. Lewis, S. Jerrod Smith, Stephanie D. Buck, and Scott A. Strong

Prepared in cooperation with Tulsa County

Scientific Investigations Report 2011-5091 


\section{U.S. Department of the Interior \\ KEN SALAZAR, Secretary \\ U.S. Geological Survey \\ Marcia K. McNutt, Director}

U.S. Geological Survey, Reston, Virginia: 2011

This and other USGS information products are available at http://store.usgs.gov/
U.S. Geological Survey
Box 25286 , Denver Federal Center
Denver, CO 80225
To learn about the USGS and its information products visit http://www.usgs.gov/
1-888-ASK-USGS

Any use of trade, product, or firm names is for descriptive purposes only and does not imply endorsement by the U.S. Government.

Although this report is in the public domain, permission must be secured from the individual copyright owners to reproduce any copyrighted materials contained within this report.

Suggested citation:

Lewis, J.M., Smith, S.J., Buck, S.D., and Strong, S.A., 2011, Estimation of annual suspended-sediment fluxes, 193195, and evaluation of geomorphic changes, 1950-2010, in the Arkansas River near Tulsa, Oklahoma: U.S. Geological Survey Scientific Investigations Report 2011-5091, 21 p. 


\section{Contents}

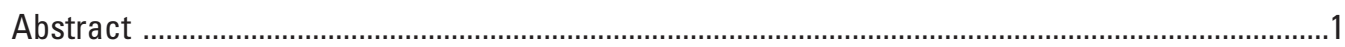

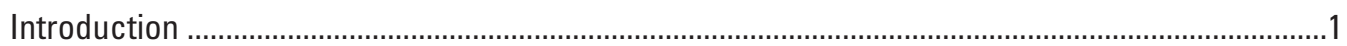

Characteristics of Sample Collection Sites and Suspended-Sediment Data ...................................

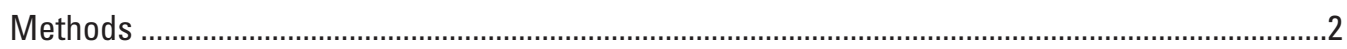

Estimating Suspended-Sediment Fluxes ................................................................................2

Streambed Channel Changes at Arkansas River at Tulsa Station ..........................................

Geographic Information System Assessment of Arkansas River Channel .............................6

Channel Centerline Length .....................................................................................

Channel Average Width .........................................................................................

Channel Lateral Migration Rate ..............................................................................

Estimation of Annual Suspended-Sediment Fluxes and Evaluation of Geomorphic Changes ......12

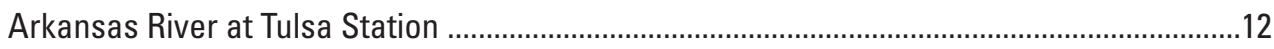

Arkansas River near Haskell Station ....................................................................................12

Streambed Channel Adjustment at Arkansas River at Tulsa Station (07164500) ....................12

Geographic Information System Assessment of Changes in Position of the Arkansas

River Channel ................................................................................................12

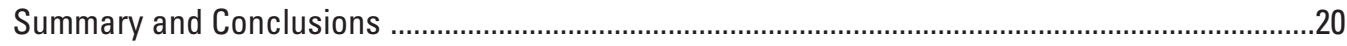

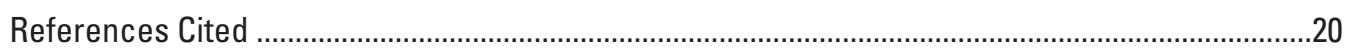

\section{Figures}

1-2. Maps showing:

1. Location of Arkansas River Basin downstream from Keystone Dam, Keystone Lake, Zink Dam, and selected U.S. Geological Survey streamflowgaging stations east-central Oklahoma ......................................................................3

2. Study segments, major tributaries, and drainage basins for the Arkansas River study reach between Keystone Dam and the Tulsa-Wagoner County line, Oklahoma: study segments end at (A) State Highway 97, (B) Interstate 244 / U.S. Highway 75, (C) Interstate 44 / State Highway 66, (D) Creek Turnpike, (E) Memorial Road, and (F) Tulsa-Wagoner County line

3. Digitized streambanks for each study segment below Keystone Dam in Tulsa, Oklahoma: study segments end at (A) State Highway 97, (B) Interstate 244 / U.S. Highway 75, (C) Interstate 44 / State Highway 66, (D) Creek Turnpike, (E) Memorial Road, and (F) Tulsa-Wagoner County line

4-9. Graphs showing:

4. Sediment rating curves for Arkansas River at Tulsa, Oklahoma, streamflowgaging station (a) linear regression, (b) second-order polynomial regression for the period 1931-64 and two curves (c) linear regression, (d) second-order polynomial regression for the period 1965-95

5. Estimated annual flow-weighted suspended-sediment concentrations at the Arkansas River at Tulsa, Oklahoma, streamflow-gaging station, 1931-95

6. Sediment rating curves for Arkansas River near Haskell, Oklahoma, streamflow-gaging station (a) linear regression, (b) second-order polynomial regression for the period 1973-82. 
7. Annual flux estimates for the Arkansas River near Haskell streamflowgaging station, 1973-82

8. Streambed change over a 35-year period from 1970-2005 at Arkansas River at Tulsa station 15

9. Streambed change before and after the completion of Zink Dam at Arkansas River at Tulsa station

10-11. Graphs of:

10. Annual change in channel centerline length and channel average width for study segments of the Arkansas River study reach between Keystone Dam and the Tulsa-Wagoner County line, Oklahoma: study segments end at (A) State Highway 97, (B) Interstate 244 / U.S. Highway 75, (C) Interstate 44 / State Highway 66, (D) Creek Turnpike, (E) Memorial Road, and (F) Tulsa-Wagoner County line

11. Channel lateral migration rate for study segments of the Arkansas River study reach between Keystone Dam and the Tulsa-Wagoner County line, Oklahoma: study segments end at (A) State Highway 97, (B) Interstate 244 / U.S. Highway 75, (C) Interstate 44 / State Highway 66, (D) Creek Turnpike, (E) Memorial Road, and (F) Tulsa-Wagoner County line

\section{Tables}

1. Summary characteristics of selected suspended-sediment sampling stations in the Arkansas River Basin near Tulsa, Oklahoma

2. Summary characteristics of annual suspended-sediment and streamflow data for selected stations in the Arkansas River Basin

3. Percentage within each flow range for days when suspended-sediment samples were collected and percentage within each flow range of total days for selected stations in the Arkansas River Basin

4. Morphological metrics and rates of change for study segments and the Arkansas River channel study reach between Keystone Dam and the Tulsa-Wagoner County line, Oklahoma

5. Comparison of estimated annual suspended-sediment fluxes using rating curves for the Arkansas River at Tulsa, Oklahoma, streamflow-gaging station (1931-95) ........18

6. Comparison of estimated annual suspended-sediment fluxes using rating curves for the Arkansas River near Haskell streamflow-gaging station (1973-82) 


\section{Conversion Factors}

\section{Inch/Pound to SI}

\begin{tabular}{|c|c|c|}
\hline Multiply & By & To obtain \\
\hline \multicolumn{3}{|c|}{ Length } \\
\hline foot $(\mathrm{ft})$ & 0.3048 & meter (m) \\
\hline mile (mi) & 1.609 & kilometer (km) \\
\hline \multicolumn{3}{|c|}{ Area } \\
\hline square mile $\left(\mathrm{mi}^{2}\right)$ & 2.590 & square kilometer $\left(\mathrm{km}^{2}\right)$ \\
\hline \multicolumn{3}{|c|}{ Volume } \\
\hline square foot $\left(\mathrm{ft}^{2}\right)$ & 0.09290 & square meter $\left(\mathrm{m}^{2}\right)$ \\
\hline \multicolumn{3}{|c|}{ Flow rate } \\
\hline acre-foot per year (acre-ft/yr) & 1,233 & cubic meter per year $\left(\mathrm{m}^{3} / \mathrm{yr}\right)$ \\
\hline foot per year (ft/yr) & 0.3048 & meter per year (m/yr) \\
\hline cubic foot per second $\left(\mathrm{ft}^{3} / \mathrm{s}\right)$ & 0.02832 & cubic meter per second $\left(\mathrm{m}^{3} / \mathrm{s}\right)$ \\
\hline \multicolumn{3}{|c|}{ Mass } \\
\hline metric ton (MT) & $10^{6}$ & Megatonne (Mt) \\
\hline
\end{tabular}

Vertical coordinate information is referenced to the National Geodetic Vertical Datum of 1929 (NGVD 29).

Horizontal coordinate information is referenced to the North American Datum of 1983 (NAD 83).

Elevation, as used in this report, refers to distance above the vertical datum.

Suspended-sediment concentrations in water are given in milligrams per liter $(\mathrm{mg} / \mathrm{L})$ or micrograms per liter $(\mu \mathrm{g} / \mathrm{L})$. 



\title{
Estimation of Annual Suspended-Sediment Fluxes, 1931- 95, and Evaluation of Geomorphic Changes, 1950-2010, in the Arkansas River near Tulsa, Oklahoma
}

\author{
By Jason M. Lewis, S. Jerrod Smith, Stephanie D. Buck, and Scott A. Strong
}

\section{Abstract}

An understanding of fluvial sediment transport and changing channel morphology can assist planners in making responsible decisions with future riverine development or restoration projects. Sediment rating curves can serve as simple models and can provide predictive tools to estimate annual sediment fluxes. Sediment flux models can aid in the design of river projects by providing insight to past and potential future sediment fluxes. Historical U.S. Geological Survey suspendedsediment and discharge data were evaluated to estimate annual suspended-sediment fluxes for two stations on the Arkansas River located downstream from Keystone Dam in Tulsa County. Annual suspended-sediment fluxes were estimated from 1931-95 for the Arkansas River at Tulsa streamflowgaging station (07164500) and from 1973-82 for the Arkansas River near Haskell streamflow-gaging station (07165570). The annual flow-weighted suspended-sediment concentration decreased from 1,970 milligrams per liter to 350 milligrams per liter after the completion of Keystone Dam at the Tulsa station. The streambed elevation at the Arkansas River at Tulsa station has changed less than 1 foot from 1970 to 2005, but the thalweg has shifted from a location near the right bank to a position near the left bank. There was little change in the position of most of the banks of the Arkansas River channel from 1950 to 2009 . The most substantial change evident from visual inspection of aerial photographs was an apparent decrease in sediment storage in the form of mid-channel and meander bars. The Arkansas River channel between Keystone Dam and the Tulsa-Wagoner County line showed a narrowing and lengthening (increase in sinuosity) over the transition period 1950-77 followed by a steady widening and shortening of the river channel (decrease in sinuosity) during the post-dam (Keystone) periods 1977-85, 1985-2003, and 2003-10.

\section{Introduction}

Estimation of suspended-sediment fluxes (or loads) is essential for understanding the amount of sediment that is carried by a river. Actual measurement of sediment fluxes is preferred but difficult to obtain, so estimates based on field data give the best possible insight into sediment-transport conditions. This estimation can assist planners in making responsible decisions with future riverine development or restoration projects and in planning for reservoir infilling, water-quality issues, and channel-bed-mining operations. Flow-regime changes cause changes in sediment dynamics including erosion and deposition, which in turn cause changes in stream-channel morphology. Changes in annual suspendedsediment fluxes are likely to produce geomorphic changes in the stream channel. Knowledge of sediment fluxes and how a river has changed over time can be useful in planning for the future.

The Arkansas River, in the vicinity of Tulsa, Oklahoma, was once an uncontrolled prairie river but over the past century has been affected by anthropogenic activities. With completion of Keystone Dam in 1964, river dynamics downstream from the dam changed. The dam, constructed for flood control and hydropower needs, reduced the amount of sediment that flowed downstream (Williams and Wolman, 1984). Because of the urban setting of much of the Arkansas River, many of the channel banks have been lined with rip-rap for erosion control. The Arkansas River channel, in the vicinity of Tulsa, has a wide sandy bottom, braided channels, and flow controlled by releases from Keystone Dam. Within this river reach, a lowwater dam (Zink dam) was built in 1983. A study by Juracek (1999) showed the geomorphic effects of low-water dams appear to be limited to a short reach of river channel located immediately downstream from dams.

Sediment rating curves have been developed for many rivers for determining annual and seasonal sediment loads (fluxes). In the absence of actual suspended-sediment concentration data, sediment-rating curves can serve as simple models and can provide predictive tools to estimate suspendedsediment concentrations/fluxes. Horowitz and others (2001) reported that very good annual suspended-sediment flux estimates (less than or equal to or plus/minus 15 percent) could be obtained by using linear or second-order polynomial sediment rating curves, with or without a "smearing" correction. Although apparently simple in concept, critical evaluation of 
the data, careful application of the technique, and an understanding of its limitations are required if the sediment rating curve method is to be used effectively. Over a 20 -year period, errors of less than 1 percent in total flux can be achieved using a single rating curve based on data spanning the entire period (Horowitz, 2003). Sediment flux models can aid in the design of river projects by providing insight to past and potential future sediment fluxes.

Tulsa County has developed a master plan for improving the Arkansas River corridor from below Keystone Dam to the Tulsa-Wagoner County line. Some of the primary goals for the plan include: improving riparian habitat along the corridor; bank stabilization; and building and enhancing dams, bridges, and amenities (Carter and Burgess, Inc., 2004; Guernsey and others, 2005). One component of the Arkansas River that needs further evaluation is fluvial sediment transport. A better understanding of suspended-sediment concentrations, annual fluxes, and geomorphic changes associated with the Arkansas River can assist planners and engineers in properly designing riparian enhancement projects.

This report presents the results of a cooperative study by the U.S. Geological Survey (USGS) and Tulsa County to estimate annual suspended-sediment fluxes for two streamflowgaging stations within the Arkansas River Basin near Tulsa, Oklahoma. Regression equations were developed for each station to predict annual suspended-sediment fluxes in the future. An evaluation of streambed changes over time at the Arkansas River at Tulsa station also is presented. Methods and results presented in this report were obtained by using a geographical information system (GIS) to evaluate geomorphic changes over time in the study reach of the Arkansas River. Study objectives were met by using available USGS suspendedsediment and streamflow-gaging station information, and aerial photography provided by Tulsa County. Results presented in this report will assist Tulsa County to better understand annual sediment fluxes and how the channel of the Arkansas River has changed over time.

Because of the urban setting of much of the Arkansas River study reach, many of the channel banks have been lined with rip-rap for erosion control. The effectiveness of these and other erosion control structures was not analyzed as part of this study. However, it is likely that these structures affect the rate of erosion and migration of channel banks over most of the study segments.

\section{Characteristics of Sample Collection Sites and Suspended-Sediment Data}

The USGS streamflow-gaging station Arkansas River at Tulsa, Oklahoma (07164500), was established in 1904 by the United States Weather Bureau and is currently (2011) operated in cooperation with the United States Army Corps of Engineers (USACE). This streamflow-gaging station originally was associated with the old bridge located on U.S.
Highway 66 until 1986, when the gage was moved to the new Arkansas River Bridge located 60 feet upstream from the old bridge on Interstate 244 (fig. 1). The Tulsa station is located 10.1 miles upstream from Polecat Creek and 15.1 miles downstream from Keystone Dam. Keystone Dam, established in 1964, regulates flow, except for the 109 square miles between the Keystone Dam and the Tulsa station. Drainage area of the Tulsa station is 74,615 square miles of which 12,541 square miles are noncontributing. Since 1983, the surface-water stage control for the Tulsa station has been the John Zink (Zink) low-water dam located 2.5 miles downstream from the Arkansas River at Tulsa streamflow-gaging station. The downstream side of the bridge is marked in 20-foot intervals and the channel is 1,500 feet wide (a recent measurement from top right bank to top left bank).

The USGS streamflow-gaging station Arkansas River near Haskell, Oklahoma (07165570), was established in June 1972. The Haskell station is located downstream from State Highway 104, 2 miles east of the town of Haskell, and 23.5 miles upstream from the confluence with the Verdigris River (fig. 1). The drainage area for the Haskell station is 75,473 square miles, of which 12,541 square miles are noncontributing.

The periods of sediment and streamflow data collection varied at each streamflow-gaging station used in the analyses (table 1). Historically there have been 1,839 suspendedsediment samples collected at the Tulsa station from 1930-95 (table 2). Before the completion of Keystone Dam, 1,318 samples were collected from the 1930-64 water years. After completion of the dam, 521 samples were collected during the 1965-95 water years. There were 241 suspended-sediment samples collected at the Haskell station from the 1973-82 water years (table 2).

There are limitations with the datasets at the Tulsa station and the Haskell station. Samples were collected by the USGS and the USACE. Most of the samples after 1970 were collected using a depth integrated method by the USGS (U.S. Geological Survey, 2006), whereas, the methods used for collecting samples before 1970 are uncertain.

\section{Methods}

\section{Estimating Suspended-Sediment Fluxes}

At each streamflow-gaging station, annual suspendedsediment fluxes were estimated using available data for each water year (defined as the 12-month period from October 1 through September 30 and is designated by the year the period ends). Annual suspended-sediment flux estimates were calculated using a relation of discharge to suspendedsediment concentration known as a sediment-rating (sediment transport) curve (Horowitz, 2003). The equation to calculate sediment fluxes or loads is the product of discharge, multiplied 


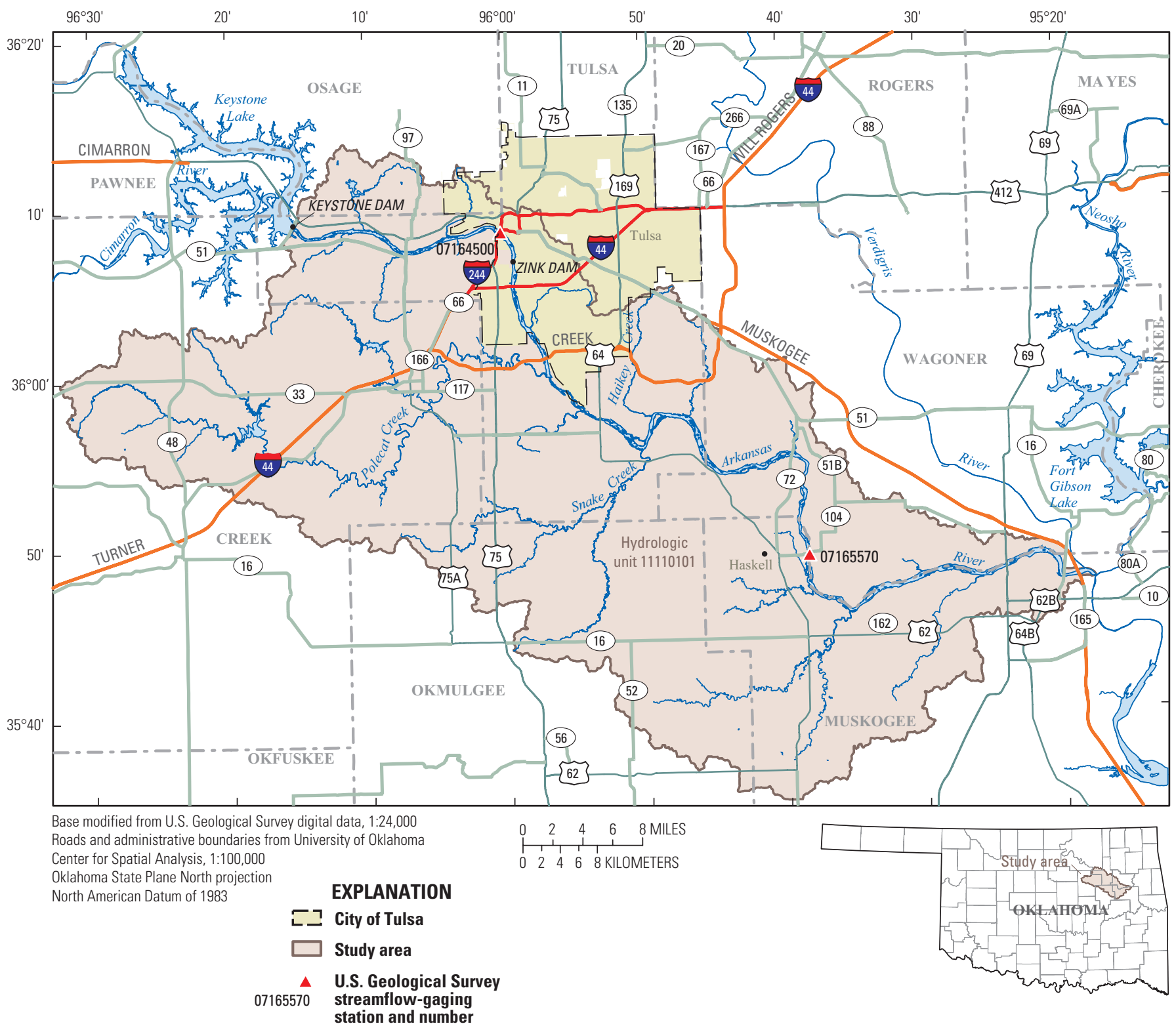

Figure 1. Location of Arkansas River Basin downstream from Keystone Dam, Keystone Lake, Zink Dam, and selected U.S. Geological Survey streamflow-gaging stations east-central Oklahoma.

by suspended-sediment concentration, and multiplied by a conversion factor (Porterfield, 1977) to obtain the appropriate mass and time units:

Flux (metric tons per day) $=$ Discharge (cubic feet per second) * suspended-sediment concentration (milligrams per liter) $* 0.00245$

An extrapolation procedure, which determines the log-log regression relation of suspended-sediment concentration to discharge, was used in this study to estimate the suspendedsediment fluxes for all days. The accuracy of this approach depends on the sampling frequency and how well the samples represented the ranges of flow at each station (table 3 ). This procedure can produce very good results (less than or equal to plus or minus 15 percent from measured results) using linear or second-order polynomial sediment rating curves, with and without a "smearing" correction (Horowitz and others, 2001; Horowitz, 2003).

Using this procedure, all of the available discharge and suspended-sediment data for the Arkansas River at Tulsa, Oklahoma (07164500), and Arkansas River near Haskell, Oklahoma (07165570), stations were analyzed (U.S. Geological Survey, 2010). The available data for the Tulsa station were divided into two time periods (1930-64, 1965-95) to correspond to the periods before and after construction of the Keystone Dam. Available data for the Haskell station included the period 1973-82. These time periods were the 
Table 1. Summary characteristics of selected suspended-sediment sampling stations in the Arkansas River Basin near Tulsa, Oklahoma.

$\left[\mathrm{ft}^{3} / \mathrm{s}\right.$, cubic feet per second; $\mathrm{mi}^{2}$, square miles]

\begin{tabular}{|c|c|c|c|c|c|c|c|}
\hline Station name & $\begin{array}{l}\text { Station } \\
\text { identifier }\end{array}$ & $\begin{array}{l}\text { Period of } \\
\text { suspended- } \\
\text { sediment } \\
\text { record }^{\mathrm{a}}\end{array}$ & $\begin{array}{l}\text { Period of } \\
\text { streamflow } \\
\text { recorda }\end{array}$ & $\begin{array}{l}\text { Period } \\
\text { of record } \\
\text { used in } \\
\text { sediment- } \\
\text { rating curve } \\
\text { analyses }^{\mathrm{a}}\end{array}$ & $\begin{array}{l}\text { Long-term } \\
\text { mean } \\
\text { annual } \\
\text { streamflow } \\
\left(\mathrm{ft}^{3} / \mathbf{s}^{\mathrm{b}}\right.\end{array}$ & $\begin{array}{c}\text { Period of } \\
\text { record used } \\
\text { in determi- } \\
\text { nation of } \\
\text { long-term } \\
\text { mean annual } \\
\text { streamflow }\end{array}$ & $\begin{array}{c}\text { Drainage } \\
\text { area } \\
\left(\mathrm{mi}^{2}\right)\end{array}$ \\
\hline Arkansas River at Tulsa, Oklahoma & 07164500 & $\begin{array}{l}1930-31 \\
1939-95\end{array}$ & $1925-2011$ & $1931-95$ & $8,907^{\mathrm{c}}$ & 1965-2009 & 74,615 \\
\hline Arkansas River near Haskell, Oklahoma & 07165570 & $\begin{array}{r}1973-82 \\
1986-88\end{array}$ & 1972-2011 & 1972-83 & 10,890 & 1973-2009 & 75,473 \\
\hline
\end{tabular}

${ }^{\text {a }}$ Source: U.S. Geological Survey (2010).

b Source: U.S. Geological Survey annual water data report accessed through U.S. Geological Survey (2010).

c Prior to regulation, $1926-64,6,554 \mathrm{ft}^{3} / \mathrm{s}$.

only times suspended-sediment samples were collected at the two streamflow-gaging stations.

For each streamflow-gaging station and time period, the suspended-sediment concentration and daily mean discharge data were combined into a single calibration set and logtransformed. Linear and polynomial regression equations subsequently were calculated and evaluated using methods described in Helsel and Hirsch (2002). If the residual analysis performed for each regression was determined to be random then predicted daily suspended-sediment concentrations were calculated for each acceptable sediment rating curve. The daily suspended-sediment concentrations subsequently were used to calculate the daily fluxes for each sample day for each rating curve. To eliminate or reduce a bias that can occur when converting data from log-transformed to arithmetic scale a "smearing correction" was applied (Duan, 1983). The daily fluxes subsequently were summed to produce a measure of total flux. This approach produced four flux estimates: (1) linear uncorrected, (2) linear "smearing" corrected, (3) polynomial uncorrected, and (4) polynomial "smearing" corrected. This procedure compares the total fluxes from each of the four estimates with the calibration (field) data set (Horowitz and others, 2001, Horowitz, 2003; Horowitz, 2008). The regression equation that produced a total flux that most closely matched the calibration set was used to estimate suspendedsediment concentrations where no data were available. Total flux values are presented in megatonnes. A "tonne" is a metric ton, with a megatonne being equal to one million metric tons.

\section{Streambed Channel Changes at Arkansas River at Tulsa Station}

Historical streambed cross sections obtained as part of USGS discharge measurements from the bridge at the Arkansas River at Tulsa, Oklahoma, streamflow-gaging station
(07164500) were evaluated to determine possible changes of the elevation and location of the streambed channel over time. These cross sections were analyzed to investigate whether: (1) the streambed changed with time because of sediment deposition, erosion, or both, and (2) the installation of the Zink low-water dam had any influence on streambed elevations.

Cross-section evaluation was conducted using the depths below water surface obtained during flow measurements to the nearest hundredth of a foot. The period of record used for this analysis included measurements made from 1970 through 2005. This station has permanent markings on the bridge deck beginning at an initial point (marked 0 ) above the proximity of the right bank and marked in 20-foot increments. Using discharge measurements at this location is advantageous because the cross sections were measured using the same width increments marked on the bridge deck. All measurements used in this analysis begin at the mark of 140 feet from the initial reference mark of zero. The streambed-depth measurements could be compared because the same width increments marked on the bridge deck were used. Cross sections selected for graphical analysis also had to fit within a specified gage height and discharge range to reduce variability.

Only cross sections measured from the bridge were used in this analysis, providing the least variation in location of each vertical transect along the cross section used to measure flow. Flow measurements obtained from the 1970s predominantly were conducted starting from the left edge of water. Beginning in 1980, flow measurements were made starting at the right edge of water. To compare the streambed depths using the same permanent bridge deck markings, increments were re-assigned as if the measurement started from the right edge of water. This adjustment made all the width increments comparable.

For the cross-sectional analysis, measurements that had only a 5-percent difference from the mean gage height and discharge were used. The 5 -percent criteria was arbitrarily 
Table 2. Summary characteristics of annual suspended-sediment and streamflow data for selected stations in the Arkansas River Basin.

[mg/L, milligrams per liter; $\mathrm{ft}^{3} / \mathrm{s}$, cubic feet per second]

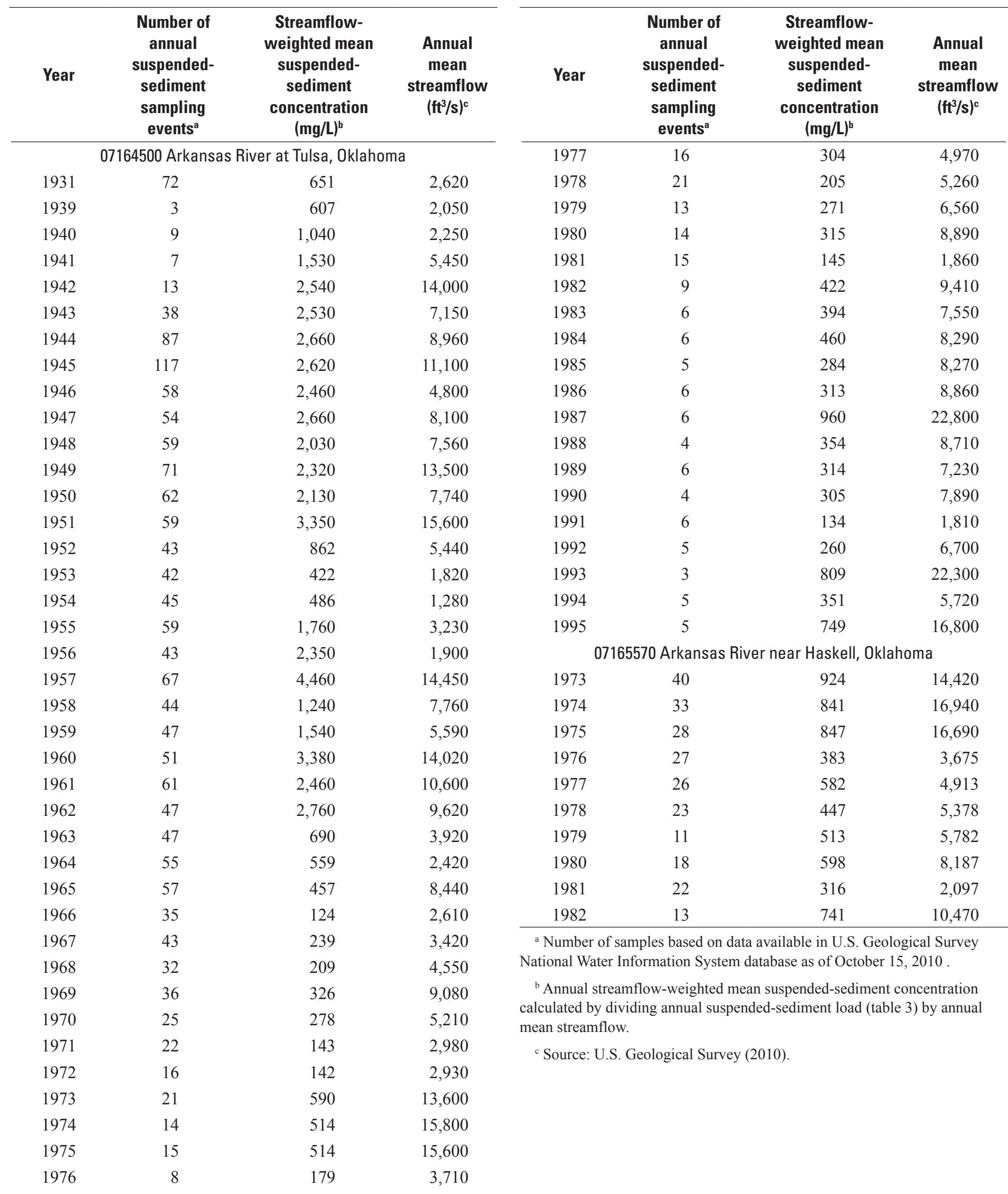


Table 3. Percentage within each flow range for days when suspended-sediment samples were collected and percentage within each flow range of total days for selected stations in the Arkansas River Basin.

$\left[\mathrm{ft}^{3} / \mathrm{s}\right.$, cubic feet per second; >, greater than $]$

\begin{tabular}{cccccc}
\hline $\begin{array}{c}\text { Stream } \\
\text { discharge } \\
\left(\mathbf{f t}^{3} \mathbf{s} \text { ) }\right.\end{array}$ & \multicolumn{2}{c}{$\begin{array}{c}\text { Arkansas River at } \\
\text { Tulsa (1931-95) }\end{array}$} & & \multicolumn{2}{c}{$\begin{array}{c}\text { Arkansas River near } \\
\text { Haskell (1973-82) }\end{array}$} \\
\cline { 2 - 3 } \cline { 5 - 6 } & $\begin{array}{c}\text { Samples } \\
\text { collected } \\
\text { (percent) }\end{array}$ & $\begin{array}{c}\text { Total } \\
\text { days } \\
\text { (percent) }\end{array}$ & & $\begin{array}{c}\text { Samples } \\
\text { collected } \\
\text { (percent) }\end{array}$ & $\begin{array}{c}\text { Total } \\
\text { days } \\
\text { (percent) }\end{array}$ \\
\hline $0-500$ & 7.1 & 8.2 & & 13 & 4.1 \\
$501-5,000$ & 47 & 56 & & 41 & 50 \\
$5,001-10,000$ & 12 & 16 & & 11 & 20 \\
$10,001-50,000$ & 26.4 & 18 & & 30 & 25.2 \\
$>50,000$ & 7.3 & 1.5 & & 4.2 & 1.5 \\
\hline
\end{tabular}

selected as a way to choose discharge measurements close to one another in stage and flow values and also to limit variability. Preliminary analysis of all cross sections measured from the bridge resulted in a mean gage height of 4.7 feet. Only measurements within plus or minus 5 percent of 4.7 feet were used in this analysis. The same methodology was applied to discharge, making the range of flow 13,900-14,600 cubic feet per second. Cross sections, measured in the selected range of gage height and discharge, were used to evaluate the change in streambed morphology at the Tulsa station.

The gage heights determined from discharge measurements were converted to the National Geodetic Vertical Datum of 1929 (NGVD 29), so that the elevation of the streambed was measured in reference to the same datum as land-surface elevation. Discharge measurements were made from the old bridge at the location of U.S. Highway 66 until 1986 when the Tulsa station was relocated to the new Interstate 244 bridge. The gage datum for Arkansas River at Tulsa, Oklahoma streamflow-gaging station is $615.23 \mathrm{ft}$ (NGVD 29) for the old and current bridge locations. The final elevations of the streambed were determined by adding the gage datum and mean gage height to the measured streambed depth.

Streambed depths were evaluated in 10-year increments beginning in 1970 and ending in 2009. For each 10-year period, an average of three discharge measurements was used to determine streambed elevations. The 10 -year period from 1990-99 had only two discharge measurements that met the specified criteria. For the 10-year period from 2000-09, there were three discharge measurements from 2000-05 that met the gage height and discharge criteria because of the introduction of hydroacoustic instrumentation to measure streamflow after 2005 .

\section{Geographic Information System Assessment of Arkansas River Channel}

Aerial orthophotographs (geographically corrected aerial photograph) of the Arkansas River corridor in Tulsa County were obtained in digital format from Tulsa County (Gaylon Pinc, PMg, written commun., 2010). The collection included tiled photo sets from 1950, 1954, 1966, 1977, 1985, and 2010. Additional aerial orthophotographs were obtained in digital format from the National Agriculture Imagery Program (NAIP) for 2003, 2006, and 2008 (State of Oklahoma, 2003, 2006, 2008). After a survey of available photographic coverage, image clarity, and spatial accuracy in GIS, the photograph sets for 1950, 1977, 1985, 2003, and 2010 were selected to be used for analysis of changes in position of Arkansas River channel banks. Aerial photographs from 1977, 1985, 2003, and 2010 were available for the Arkansas River channel from Keystone Dam to the Tulsa-Wagoner County line (fig. 2). The 1950 aerial photography was only available within or near the city of Tulsa, or about half of the river distance between Keystone Dam and the Tulsa-Wagoner County line (fig. 2).

For each of the five selected years $(1950,1977,1985$, 2003, and 2010), the banks of the Arkansas River were digitized at a scale of 1:6,000 (fig. 3). This scale only allows computation of general changes in river morphology over many miles; local scale changes in river morphology could not be evaluated at this scale. The edge of water was not used in digitization of riverbanks because annual aerial photographs show the river at different discharge and stage conditions, leading to very different water-surface areas and channel widths, especially at discharges less than 15,000 cubic feet per second. Instead, the banks of the river bankfull channel were delineated primarily by the presence of vegetation and evidence of recent fluvial activity (Copeland and others, 2000; VanLooy and Martin, 2005). In segments where locations of riverbanks were not obvious, photographs from the next or previous year were used for comparison. Mid-channel bars (bars surrounded by water) were considered to be part of the bankfull channel. Point bars on the inside of meander bends were considered to be part of the bankfull channel only when unvegetated, and only up to an elevation where a bar showed no obvious signs of reworking by flowing water. Tops of point bars, which appeared to have been altered by eolian processes, were not considered to be part of the bankfull channel. If a vegetated point bar was completely bisected by a channel braid, it was considered to be part of the bankfull channel (Shields and others, 2000). Any other bars and sediment deposits that showed evidence of human alteration, such as by all-terrain vehicle tracks, sediment mining, and aquaculture activities, were not considered part of the bankfull channel.

At tributaries where large volumes of sediment are periodically deposited by tributary flood flows, the Arkansas River bankfull channel was defined by delineating a boundary where the evidence of reworking of sediment transitioned from being dominated by tributary flows to being dominated by Arkansas River flows. The 2008 NAIP aerial photographs for Tulsa County were used to check the quality of the 2003 and 2010 digitized banks because the 2008 photography was collected when the river stage was relatively high, and the river was 


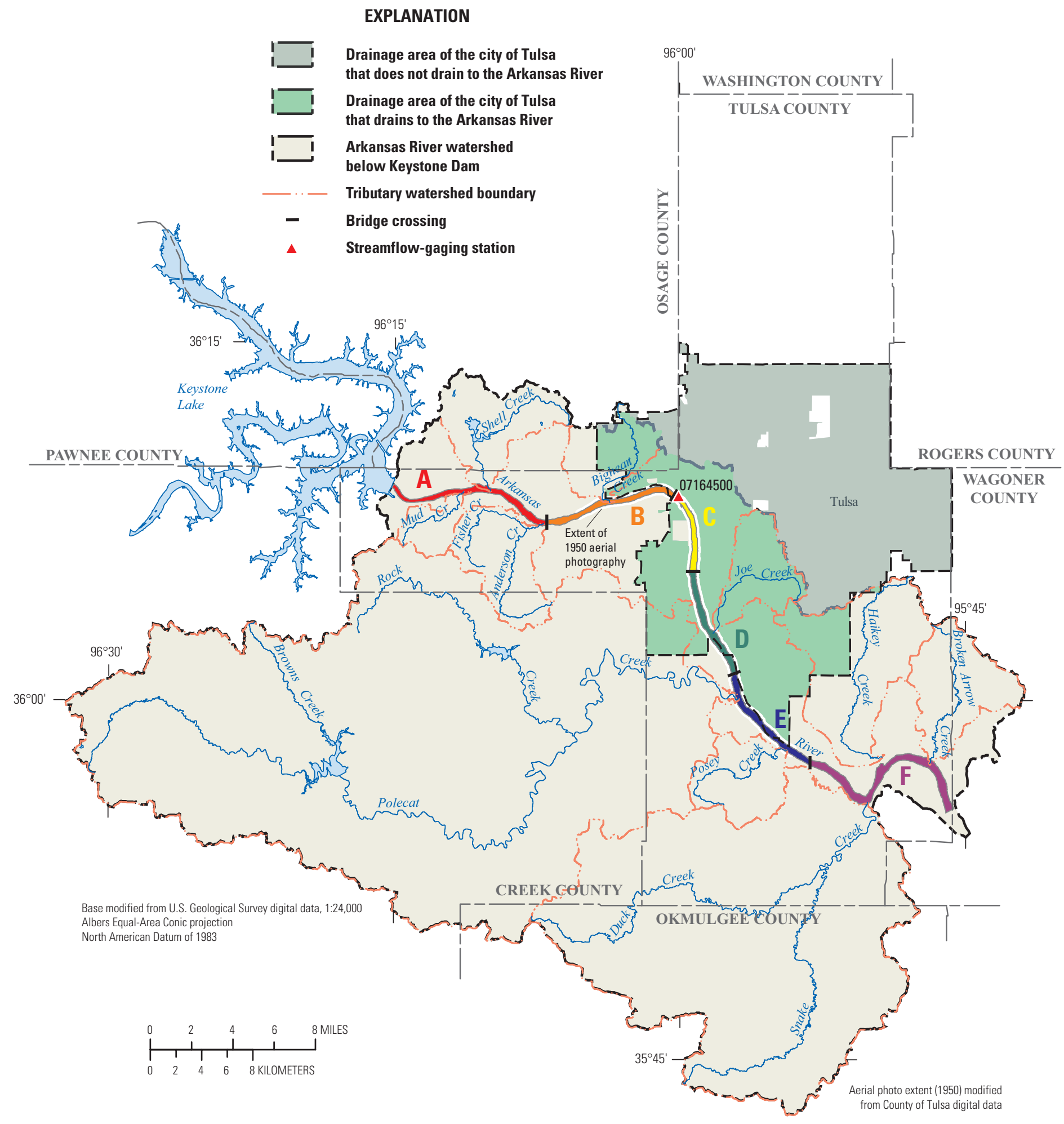

Figure 2. Study segments, major tributaries, and drainage basins for the Arkansas River study reach between Keystone Dam and the Tulsa-Wagoner County line, Oklahoma: study segments end at (A) State Highway 97, (B) Interstate 244 / U.S. Highway 75, (C) Interstate 44 / State Highway 66, (D) Creek Turnpike, (E) Memorial Road, and (F) Tulsa-Wagoner County line. 


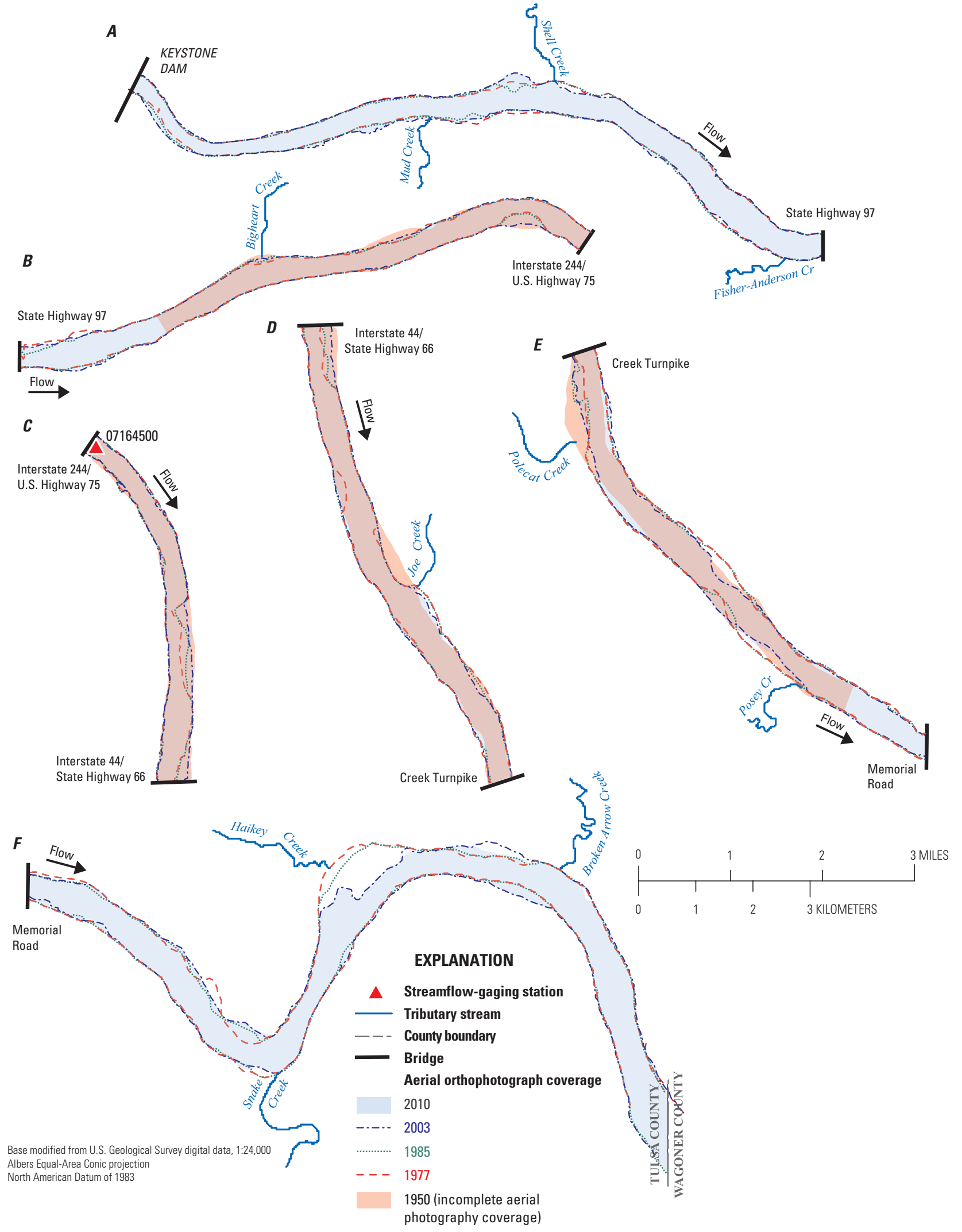

Figure 3. Digitized streambanks for each study segment below Keystone Dam in Tulsa, Oklahoma: study segments end at (A) State Highway 97, (B) Interstate 244 / U.S. Highway 75, (C) Interstate 44 / State Highway 66, (D) Creek Turnpike, (E) Memorial Road, and (F) Tulsa-Wagoner County line. 
approaching bankfull width (but not necessarily bankfull discharge) in most reaches. When the 2008 photographs were taken (July 14, 2008), the discharge at streamflowgaging station 07164500 was about 15,000 cubic feet per second. Therefore, it is believed the banks digitized in this study represent the water surface at a minimum discharge of 15,000-20,000 cubic feet per second. Since the closure of Keystone Dam, a discharge of this magnitude occurs about annually (on average) at the Tulsa station (Lewis and Esralew, 2009). According to Leslie and others (2000), who studied changes in least tern habitat near streamflow-gaging station 07164500 , bankfull discharge was about 90,000 cubic feet per second in 1992-93. Because the Arkansas River study segments have a wide channel $(0.209$ to 0.342 miles; table 4) with relatively steep banks, the change in wetted channel width likely would be small with discharges ranging from 20,000 to 90,000 cubic feet per second. The most recent stage-discharge rating curve (2011) for streamflow gaging station 07164500 did not have an obvious slope break that could be interpreted as an indicator of bankfull stage (James Wellman, U.S. Geological Survey, written commun., 2011).

The bankfull discharge and bankfull channel are notoriously difficult to evaluate, partly because of the lack of consistent, universally applicable definitions of the terms and their morphological markers (Williams, 1978). The bankfull discharge, which completely fills the bankfull channel, is generally defined as the "maximum discharge that a channel can convey without overflowing onto the floodplain" (Copeland and others, 2000). However, the delineation of the bankfull channel from inspection of aerial photographs can be problematic, especially in channels undergoing adjustment to changes in flow regime. The Arkansas River channel within the study reach is unstable and is in the process of adjusting to a regulated flow regime, including a new bankfull discharge that is probably smaller than the bankfull discharge of the unregulated channel. Comparing pre-dam and post-dam statistics at the Tulsa station, the peak discharges associated with the 2- and 5-year recurrence intervals (50 and 20 percent chance of flow being equaled or exceeded in a given year) have decreased by about 45 percent. The 2 -year peak flow decreased from 81,300 cubic feet per second for the period 1923-64 to 44,600 cubic feet per second for the period 1965-2007 (Lewis and Esralew, 2009). The 5-year peak flow decreased from 144,000 cubic feet per second for the period 1923-64 to 80,200 cubic feet per second for the period 19652007 (Lewis and Esralew, 2009). The recurrence interval of the bankfull discharge in stable channels generally is thought to be less than 10 years but may be much longer (Pickup and Warner, 1976; Williams, 1978).

The left and right banks of the Arkansas River channel were digitized for all 5 years $(1950,1977,1985,2003$, and 2010) from aerial photographs (fig. 3). That digitization formed the foundation for the computation and analysis of several morphological metrics that can be used to assess rates of channel change (table 4). Also, the study reach was divided into six segments using major river crossings (bridges) as endpoints (figs. 2-3), allowing analysis of changes in banks with distance from Keystone Dam and with time between years of available aerial photographs. Bridges were chosen as segment endpoints instead of tributary confluences because much of the observed channel changes occurred at or near tributary confluences, especially at the Polecat Creek and Haikey Creek confluences (fig. 3). Changes in the channel were quantified by comparing the centerline length (sinuosity), average width of the digitized bankfull channel, and lateral migration rate between study segments and between years of aerial photography (table 4). To aid in interpretation of channel changes, the aerial photograph pair 1950-77 was defined as a transition period between pre-dam and post-dam flow conditions, and the three remaining aerial photograph pairs (1977-85, 1985-2003, and 2003-2010) were defined as post-dam periods. Because readily usable photographs for only one year were collected prior to the construction of Keystone Dam in 1964, comparisons of pre-dam and post-dam channel changes were not possible.

\section{Channel Centerline Length}

The channel centerline was computed using the Collapse Dual Lines to Centerline tool in ESRI ArcGIS (ESRI, 2010). Channel centerlines were used for analysis of the digitized banks because the centerlines are less sensitive to potential errors in bank delineation and are more easily manipulated in GIS.

\section{Channel Average Width}

The lateral migration rate procedure (Shields and others, 2000) can fail to capture and quantify changes in the channel resulting from symmetrical channel widening or narrowing, which can be substantial for streams adjusting to regulated flow regimes. To quantify changes in average channel width, the channel area was first computed for the study segment polygons defined by the digitized channel banks and bridge crossings (fig. 2). Average channel width then was computed by dividing the channel polygon area by the channel centerline length.

\section{Channel Lateral Migration Rate}

Channel lateral migration rate, also referred to as a channel activity index, was computed using a procedure documented by Shields and others (2000). For each time interval, areas between the bankfull-channel centerlines were computed for each segment (table 4). The areas then were divided by the channel centerline length and the number of years in the time interval to arrive at an average annual rate of area change per unit length, which is reported in units of feet per year. The channel lateral migration rate is always a number greater than or equal to 0 . Therefore, this metric is not a measure of how fast the banks are moving in a particular direction but a general index of channel activity. 
Table 4. Morphological metrics and rates of change for study segments and the Arkansas River channel study reach between Keystone Dam and the Tulsa-Wagoner County line, Oklahoma.

[--, not applicable; red values, negative change $]$

\begin{tabular}{|c|c|c|c|c|c|c|c|c|c|c|c|c|c|c|c|c|c|c|c|}
\hline \multirow{4}{*}{$\begin{array}{l}\text { Study } \\
\text { segment } \\
\text { (fig. 3) }\end{array}$} & \multirow{4}{*}{ Description } & \multicolumn{9}{|c|}{ Channel centerline } & \multicolumn{9}{|c|}{ Channel polygon } \\
\hline & & \multirow{2}{*}{\multicolumn{5}{|c|}{$\begin{array}{l}\text { Length } \\
\text { (miles) }\end{array}$}} & \multicolumn{4}{|c|}{$\begin{array}{l}\text { Change in length } \\
\text { (feet per year) }\end{array}$} & \multirow{2}{*}{\multicolumn{5}{|c|}{$\begin{array}{c}\text { Area } \\
\text { (square miles) }\end{array}$}} & \multicolumn{4}{|c|}{$\begin{array}{l}\text { Change in area } \\
\text { (acres per year) }\end{array}$} \\
\hline & & & & & & & \multirow{2}{*}{$\begin{array}{c}\begin{array}{c}\text { Transi- } \\
\text { tion } \\
\text { period }\end{array} \\
\begin{array}{c}1950- \\
77\end{array}\end{array}$} & \multicolumn{3}{|c|}{$\begin{array}{l}\text { Post-dam } \\
\text { period }\end{array}$} & & & & & & \multirow{2}{*}{$\begin{array}{c}\begin{array}{c}\text { Transi- } \\
\text { tion } \\
\text { period }\end{array} \\
\begin{array}{c}1950- \\
77\end{array}\end{array}$} & \multicolumn{3}{|c|}{$\begin{array}{l}\text { Post-dam } \\
\text { period }\end{array}$} \\
\hline & & 1950 & 1977 & 1985 & 2003 & 2010 & & $\begin{array}{c}1977- \\
85\end{array}$ & $\begin{array}{c}1985- \\
2003\end{array}$ & $\begin{array}{c}2003- \\
10\end{array}$ & 1950 & 1977 & 1985 & 2003 & 2010 & & $\begin{array}{c}1977- \\
85\end{array}$ & $\begin{array}{c}1985- \\
2003\end{array}$ & $\begin{array}{c}2003- \\
10\end{array}$ \\
\hline A & Keystone Dam to OK 97 & -- & 8.65 & 8.62 & 8.63 & 8.62 & -- & -14.88 & 2.78 & -13.08 & -- & 2.108 & 2.106 & 2.243 & 2.255 & -- & -0.16 & 4.87 & 1.15 \\
\hline $\mathrm{B}$ & OK 97 to I-244 / US 75 & -- & 6.73 & 6.69 & 6.64 & 6.63 & -- & -31.97 & -14.09 & -7.40 & -- & 1.600 & 1.582 & 1.687 & 1.716 & -- & -1.48 & 3.75 & 2.66 \\
\hline B1950 & $\begin{array}{l}\text { Westernmost extent of } \\
1950 \text { aerial photography } \\
\text { coverage to I-244 / } \\
\text { US } 75\end{array}$ & 5.01 & 5.08 & 5.06 & 5.02 & 5.01 & 12.98 & -11.34 & -12.93 & -7.50 & 1.325 & 1.154 & 1.175 & 1.238 & 1.262 & -4.03 & 1.64 & 2.24 & 2.16 \\
\hline $\mathrm{C}$ & $\begin{array}{l}\text { I- } 244 \text { / US } 75 \text { to I- } 44 \text { / } \\
\text { OK } 66\end{array}$ & 4.12 & 4.14 & 4.11 & 4.05 & 4.04 & 5.11 & -17.55 & -17.75 & -13.26 & 1.109 & .866 & .904 & .996 & 1.022 & -5.76 & 3.12 & 3.24 & 2.42 \\
\hline $\mathrm{D}$ & $\begin{array}{l}\text { I-44 / OK } 66 \text { to Creek } \\
\text { Turnpike }\end{array}$ & 5.53 & 5.59 & 5.56 & 5.53 & 5.51 & 11.33 & -20.62 & -8.15 & -15.23 & 1.712 & 1.524 & 1.574 & 1.593 & 1.597 & -4.46 & 4.07 & .67 & .34 \\
\hline E1950 & $\begin{array}{l}\text { Creek Turnpike to } \\
\text { easternmost extent of } \\
1950 \text { aerial photography } \\
\text { coverage }\end{array}$ & 5.03 & 5.05 & 5.06 & 5.02 & 5.01 & 4.54 & 2.22 & -11.70 & -4.32 & 1.580 & 1.498 & 1.521 & 1.419 & 1.487 & -1.94 & 1.81 & -3.62 & 6.23 \\
\hline E & $\begin{array}{l}\text { Creek Turnpike to } \\
\text { Memorial Road }\end{array}$ & -- & 6.03 & 6.03 & 5.98 & 5.97 & -- & .79 & -15.22 & -2.13 & -- & 1.781 & 1.800 & 1.690 & 1.757 & -- & 1.52 & -3.94 & 6.20 \\
\hline $\mathrm{F}$ & $\begin{array}{l}\text { Memorial Road to Tulsa- } \\
\text { Wagoner County line }\end{array}$ & -- & 10.61 & 10.51 & 10.37 & 10.33 & -- & -64.20 & -40.81 & -27.13 & -- & 3.629 & 3.568 & 3.524 & 3.523 & -- & -4.88 & -1.55 & -.10 \\
\hline $\begin{array}{l}\text { Study } \\
\text { reach }\end{array}$ & $\begin{array}{l}\text { Keystone Dam to Tulsa- } \\
\text { Wagoner County line }\end{array}$ & -- & 41.74 & 41.52 & 41.20 & 41.10 & -- & -148.43 & -93.23 & -78.24 & -- & 14.263 & 14.292 & 14.658 & 14.849 & -- & 2.36 & 13.02 & 17.48 \\
\hline $\begin{array}{l}\text { Study } \\
\text { reach } \\
1950\end{array}$ & $\begin{array}{l}\text { Westernmost extent of } \\
1950 \text { aerial photography } \\
\text { coverage to easternmost } \\
\text { extent of } 1950 \text { aerial } \\
\text { photography coverage }\end{array}$ & 19.69 & 19.86 & 19.79 & 19.62 & 19.57 & 33.96 & -47.28 & -50.52 & -40.31 & 5.725 & 5.042 & 5.175 & 5.246 & 5.368 & -16.19 & 10.64 & 2.54 & 11.15 \\
\hline
\end{tabular}


Table 4. Morphological metrics and rates of change for study segments and the Arkansas River channel study reach between Keystone Dam and the Tulsa-Wagoner County line, Oklahoma.-Continued

[--, not applicable; red values, negative change]

\begin{tabular}{|c|c|c|c|c|c|c|c|c|c|c|c|c|c|c|c|c|c|c|}
\hline \multirow{4}{*}{$\begin{array}{l}\text { Study } \\
\text { seg- } \\
\text { ment } \\
\text { (fig. 3) }\end{array}$} & \multirow{4}{*}{ Description } & \multicolumn{9}{|c|}{ Channel average width (polygon area/centerline length) } & \multicolumn{8}{|c|}{ Channel lateral migration rate (Shields and others, 2000) } \\
\hline & & \multirow{2}{*}{\multicolumn{5}{|c|}{$\begin{array}{l}\text { Average width } \\
\text { (miles) }\end{array}$}} & \multicolumn{4}{|c|}{$\begin{array}{l}\text { Change in average width } \\
\text { (feet per year) }\end{array}$} & \multicolumn{4}{|c|}{$\begin{array}{l}\text { Area between centerlines } \\
\text { (thousands of square feet) }\end{array}$} & \multicolumn{4}{|c|}{$\begin{array}{l}\text { Lateral migration rate } \\
\text { (feet per year) }\end{array}$} \\
\hline & & & & & & & \multirow{2}{*}{$\begin{array}{c}\begin{array}{c}\text { Transi- } \\
\text { tion } \\
\text { period }\end{array} \\
1950- \\
77\end{array}$} & \multicolumn{3}{|c|}{$\begin{array}{l}\text { Post-dam } \\
\text { period }\end{array}$} & \multicolumn{2}{|l|}{$\begin{array}{c}\text { Transi- } \\
\text { tion } \\
\text { period }\end{array}$} & \multicolumn{2}{|l|}{$\begin{array}{l}\text { Post-dam } \\
\text { period }\end{array}$} & \multirow{2}{*}{ 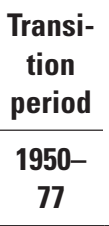 } & \multicolumn{3}{|c|}{$\begin{array}{l}\text { Post-dam } \\
\text { period }\end{array}$} \\
\hline & & 1950 & 1977 & 1985 & 2003 & 2010 & & $\begin{array}{c}1977- \\
85\end{array}$ & $\begin{array}{l}1985- \\
2003\end{array}$ & $\begin{array}{c}2003- \\
10\end{array}$ & $\begin{array}{c}1950- \\
77\end{array}$ & $\begin{array}{c}1977- \\
85\end{array}$ & $\begin{array}{l}1985- \\
2003\end{array}$ & $\begin{array}{c}2003- \\
10\end{array}$ & & $\begin{array}{c}1977- \\
85\end{array}$ & $\begin{array}{l}1985- \\
2003\end{array}$ & $\begin{array}{c}2003- \\
10\end{array}$ \\
\hline A & Keystone Dam to OK 97 & -- & 0.244 & 0.244 & 0.260 & 0.262 & -- & 0.27 & 4.57 & 1.50 & -- & $1,854.38$ & $2,593.60$ & 766.65 & -- & 5.08 & 3.16 & 2.40 \\
\hline B & OK 97 to I-244 / US 75 & -- & .238 & .237 & .254 & .259 & -- & -.68 & 5.16 & 3.59 & -- & $1,282.85$ & $1,795.73$ & 425.68 & -- & 4.51 & 2.83 & 1.73 \\
\hline B1950 & $\begin{array}{l}\text { Westernmost extent } \\
\text { of } 1950 \text { aerial } \\
\text { photography coverage } \\
\text { to I-244 / US } 75\end{array}$ & 0.264 & .227 & .232 & .247 & .252 & -7.22 & 3.18 & 4.29 & 3.92 & $2,724.92$ & 676.65 & $1,307.77$ & 304.72 & 3.81 & 3.15 & 2.72 & 1.64 \\
\hline $\mathrm{C}$ & $\begin{array}{l}\text { I-244 / US } 75 \text { to I-44 / } \\
\quad \text { OK } 66\end{array}$ & .269 & .209 & .220 & .246 & .253 & -11.81 & 7.14 & 7.56 & 5.75 & $3,346.00$ & $1,178.27$ & $2,088.90$ & 747.31 & 5.70 & 6.74 & 5.34 & 4.99 \\
\hline $\mathrm{D}$ & $\begin{array}{l}\text { I-44 / OK } 66 \text { to Creek } \\
\text { Turnpike }\end{array}$ & .310 & .273 & .283 & .288 & .290 & -7.21 & 7.05 & 1.41 & 1.31 & $4,840.08$ & $1,877.36$ & $1,695.34$ & 553.78 & 6.14 & 7.95 & 3.21 & 2.71 \\
\hline E1950 & $\begin{array}{l}\text { Creek Turnpike to } \\
\text { easternmost extent } \\
\text { of } 1950 \text { aerial } \\
\text { photography coverage }\end{array}$ & .314 & .296 & .301 & .283 & .297 & -3.44 & 2.83 & -5.25 & 10.51 & $6,031.76$ & $1,347.67$ & $4,126.33$ & 921.63 & 8.41 & 6.31 & 8.59 & 4.97 \\
\hline E & $\begin{array}{l}\text { Creek Turnpike to } \\
\text { Memorial Road }\end{array}$ & -- & .296 & .299 & .283 & .294 & -- & 2.05 & -4.68 & 8.67 & -- & $1,609.28$ & $4,587.10$ & $1,144.47$ & -- & 6.32 & 8.01 & 5.18 \\
\hline $\mathrm{F}$ & $\begin{array}{l}\text { Memorial Road to } \\
\text { Wagoner County line }\end{array}$ & -- & .342 & .340 & .340 & .341 & -- & -1.74 & .10 & .81 & -- & $4,068.44$ & $8,070.99$ & $1,988.77$ & -- & 9.08 & 8.08 & 5.19 \\
\hline $\begin{array}{l}\text { Study } \\
\text { reach }\end{array}$ & $\begin{array}{l}\text { Keystone Dam to Tulsa- } \\
\text { Wagoner County line }\end{array}$ & -- & .342 & .344 & .356 & .361 & -- & 1.69 & 3.39 & 4.19 & -- & $12,547.22$ & $22,139.42$ & $5,931.37$ & -- & 7.12 & 5.61 & 3.90 \\
\hline $\begin{array}{l}\text { Study } \\
\text { reach } \\
1950\end{array}$ & $\begin{array}{l}\text { Westernmost extent } \\
\text { of } 1950 \text { aerial } \\
\text { photography coverage } \\
\text { to easternmost } \\
\text { extent of } 1950 \text { aerial } \\
\text { photography coverage }\end{array}$ & .291 & .254 & .261 & .267 & .274 & -7.22 & 5.04 & 1.74 & 5.25 & $16,942.76$ & $5,079.95$ & $9,218.34$ & $2,527.44$ & 6.04 & 6.08 & 4.94 & 3.50 \\
\hline
\end{tabular}




\section{Estimation of Annual Suspended- Sediment Fluxes and Evaluation of Geomorphic Changes}

\section{Arkansas River at Tulsa Station}

A linear uncorrected rating curve was determined to be the most appropriate curve for estimating suspended-sediment concentrations at the Tulsa station for the period 1931-64 (fig. 4). The total flux (250 megatonnes) estimated by a linear uncorrected rating curve, most closely matched the total flux (211 megatonnes) from the calibration (actual) dataset. The total flux is the sum of all daily fluxes in which a suspendedsediment concentration sample was collected. For the period 1965-95, a corrected polynomial rating curve yielded a total flux (7.02 megatonnes) that most closely matched the total flux of the calibration (actual) dataset (6.57 megatonnes) (fig. 4). Table 5 compares annual fluxes for water years 193195 for each of the four rating curves, with the best fit estimated flux values that were selected. The average estimated annual sediment flux before construction of the Keystone Dam was 14.7 megatonnes. The average estimated annual flux for the Tulsa station after Keystone Dam construction was 3.99 megatonnes.

Flow-weighted suspended-sediment concentration is the total flux divided by the total flow for each year (Horowitz and others, 2001). Figure 5 shows annual flow-weighted suspended-sediment concentration changes over time. The data were shown in this way to normalize for flow (Horowitz and others, 2001). The median estimated flow-weighted suspended-sediment concentration of Keystone Dam before and after construction was 1,970 and 350 milligrams per liter, respectively.

\section{Arkansas River near Haskell Station}

A corrected linear rating curve was used to estimate suspended-sediment concentrations for the Arkansas River near Haskell period 1973-82 (fig. 6). The total flux (7.00 megatonnes), estimated by a corrected linear rating curve, most closely matched the total actual flux (7.34 megatonnes) from the calibration (actual) dataset. The average estimated annual flux for the Haskell station from 1973-82 is 6.5 megatonnes. Table 6 compares annual fluxes for each year for each of the four rating curves, with the best-fit predicted flux values that were selected. For the period 1973-82 the estimated annual flux ranged from 0.7 to 14.2 megatonnes (fig. 7). During the same period (1973-82) both the Haskell station and the Tulsa station had the same decreasing then increasing pattern in annual fluxes, with the Arkansas River near Haskell station always having a higher annual flux (tables 5 and 6).

\section{Streambed Channel Adjustment at Arkansas River at Tulsa Station (07164500)}

From 1970-79, the streambed elevation across the channel varied by up to 4.5 feet at the Tulsa station. The deepest section of the streambed (603.2 feet NGVD 29) was located 400 feet from the initial reference mark (zero) on the bridge deck above the right bank. The thalweg (deepest point of the river bed) of the stream was located closer to the right bank (fig. 8). During the 1980-89 period, the streambed elevation across the channel varied by up to 3.5 feet. The deepest section of the river (604.5 feet NGVD 29) was approximately 750 feet from the initial mark near the right bank, with the thalweg being near the center of the stream channel (fig. 8). From 1990-99, the streambed elevation varied across the channel by up to 3 feet. The greatest depth occurred at approximately 950 feet from the initial reference mark near the right bank. During that time period, the thalweg was located closer to the left bank (fig. 8). From 2000-05, the streambed elevation across the channel varied by 4.3 feet with the greatest depth (603.5 feet NGVD 29) occurring 1,100 feet from the initial reference mark near the right edge of water. The thalweg during that time period was located near the left bank.

Construction of the John Zink low-water dam in 1983 (downstream from the Tulsa station) substantially affected the deposition of sediment in the streambed. Mean streambed depths from measurements made during the 1970-83 period (before Zink Dam completion) were compared to the mean streambed depths from measurements made during the 1984-2005 period (after dam completion). There was a shift of the thalweg from the right side of the channel (604.1 feet bottom elevation) at 600 feet from a reference mark on the bridge above the right bank to the left side of the channel ( 604.3 feet bottom elevation) at 900 feet from initial reference mark of zero (fig. 9).

Based on the analysis of the streambed cross sections at the Tulsa station, there was a shift in the thalweg from near the right bank to near the left bank during the 35-year analysis period. Average bed elevation had minor change (less than 1.0 foot) over the entire period. Data compilations comparing streambed cross-section depths before and after the construction of the Zink low-water dam further support a shift in the thalweg from the right to the left side of the river channel (fig. 9).

\section{Geographic Information System Assessment of Changes in Position of the Arkansas River Channel}

Positive changes in channel average width indicate channel widening, and negative changes in channel average width indicate channel narrowing during the analysis period (fig. 10). Based on analysis of aerial photographs, the 2010 bankfull-channel centerline for the entire study reach 


\section{A. Linear regression, $1935-64$}

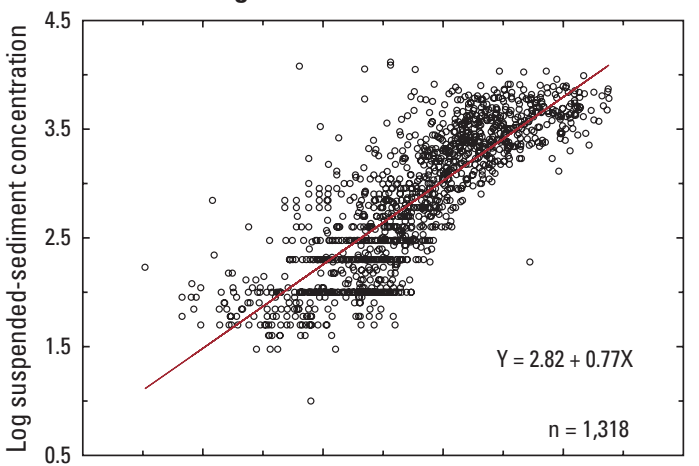

B. Second-order polynomial regression, 1935-64

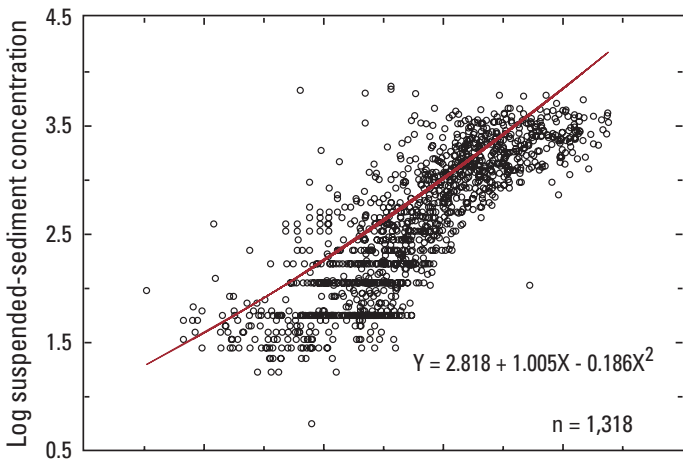

C. Linear regression, $1965-95$

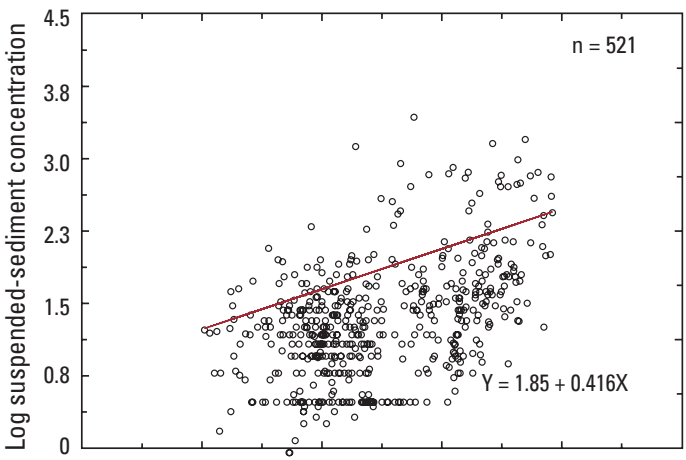

D. Second-order polynomial regression, 1965-95

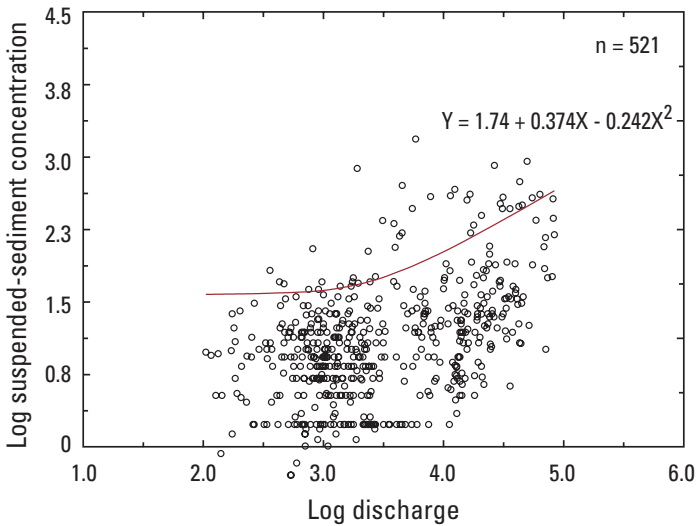

\section{EXPLANATION}

- Line for equation

Sample

n Number of samples

Coefficient of determination $\left(R^{2}\right)=0.68$ Actual Flux $=211$ Megatonnes $(\mathrm{Mt})$

Predicted Flux $=250 \mathrm{Mt}$

Corrected $^{1}$ (1.554) Predicted Flux $=388 \mathrm{Mt}$

\section{$R^{2}=0.71$}

Actual Flux $=211 \mathrm{Mt}$

Predicted Flux $=281 \mathrm{Mt}$

Corrected $^{1}$ (1.546) Predicted Flux $=435 \mathrm{Mt}$

$R^{2}=0.22$

Actual Flux $=6.57 \mathrm{Mt}$

Predicted Flux $=2.01 \mathrm{Mt}$

Corrected $^{1}$ (2.413) Predicted Flux $=4.84 \mathrm{Mt}$

\section{$R^{2}=0.25$}

Actual Flux $=6.57 \mathrm{Mt}$

Predicted Flux $=2.84 \mathrm{Mt}$

Corrected $^{1}$ (2.469) Predicted Flux $=7.02 \mathrm{Mt}$

${ }^{1}$ Duan's (1983) correction factor

Figure 4. Sediment rating curves for Arkansas River at Tulsa, Oklahoma, streamflow-gaging station (a) linear regression, (b) secondorder polynomial regression for the period 1931-64 and two curves (c) linear regression, (d) second-order polynomial regression for the period 1965-95. 


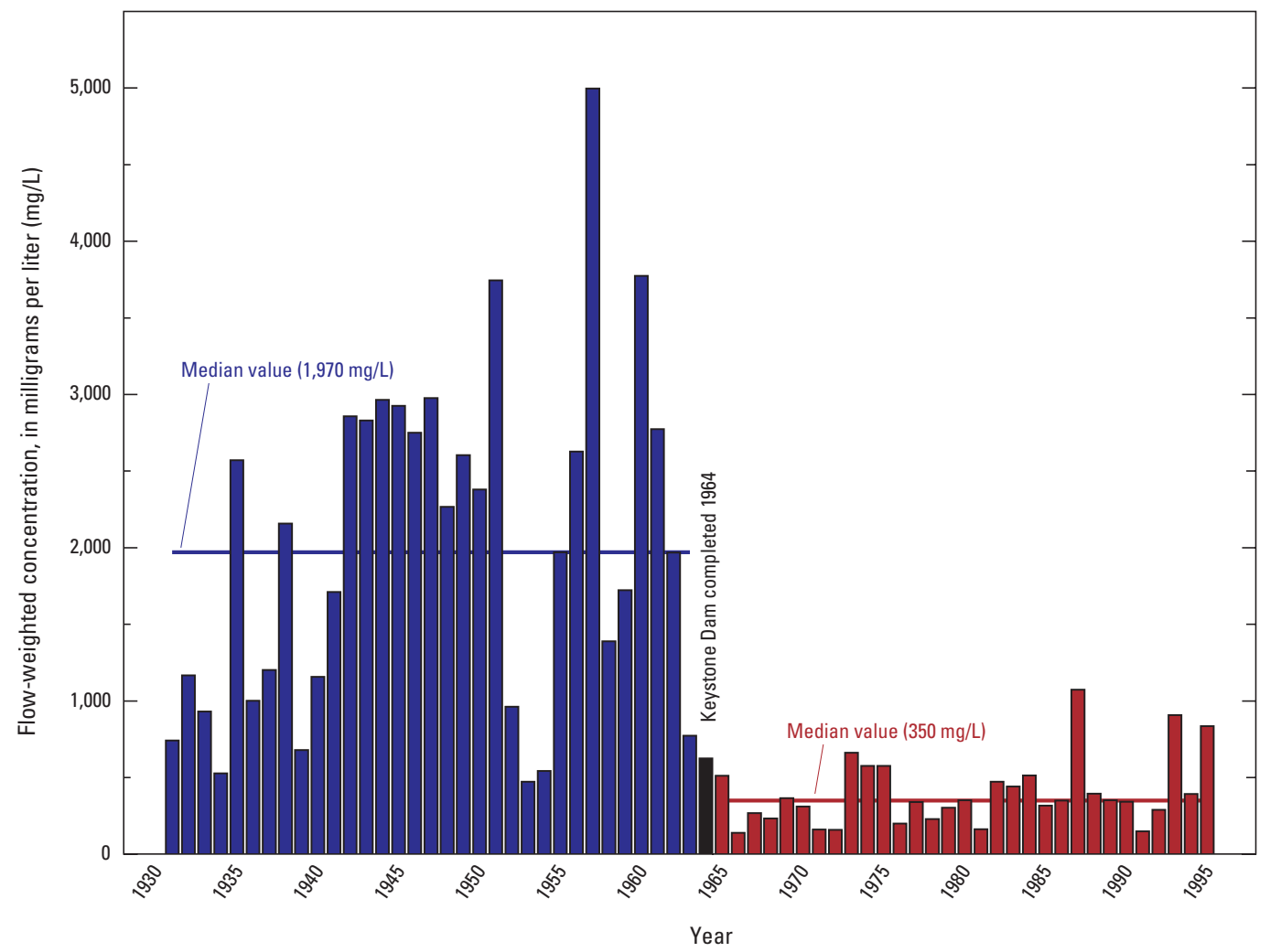

Figure 5. Estimated annual flow-weighted suspended-sediment concentrations at the Arkansas River at Tulsa, Oklahoma, streamflowgaging station, 1931-95.

A. Linear regression, $1973-82$

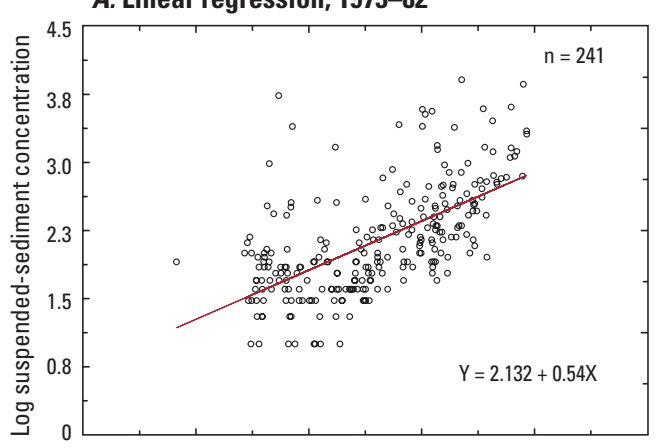

B. Second-order polynomial regression, 1973-82

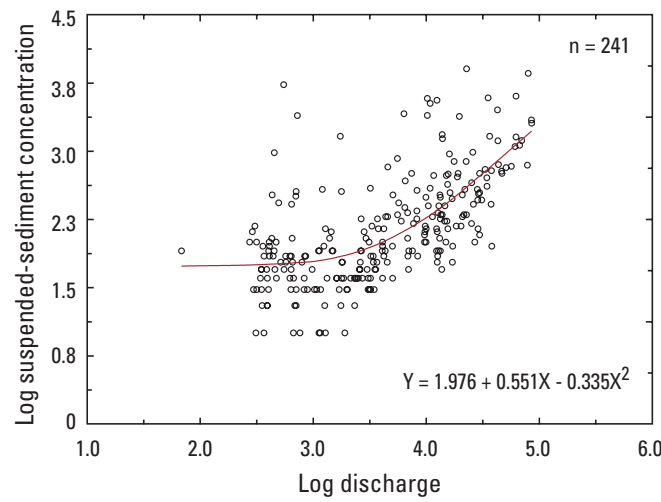

EXPLANATION

Coefficient of determination $\left(R^{2}\right)=0.37$ Actual Flux = 7.34 Megatonnes (Mt) Predicted Flux $=2.84 \mathrm{Mt}$

Corrected $^{1}$ (2.456) Predicted Flux $=7.00 \mathrm{Mt}$

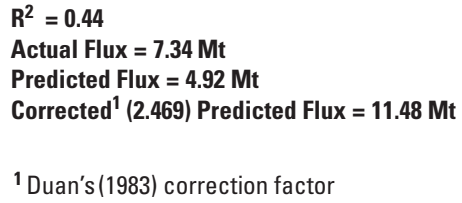

${ }^{1}$ Duan's(1983) correction factor

Figure 6. Sediment rating curves for Arkansas River near Haskell, Oklahoma, streamflow-gaging station (a) linear regression, (b) second-order polynomial regression for the period 1973-82. 


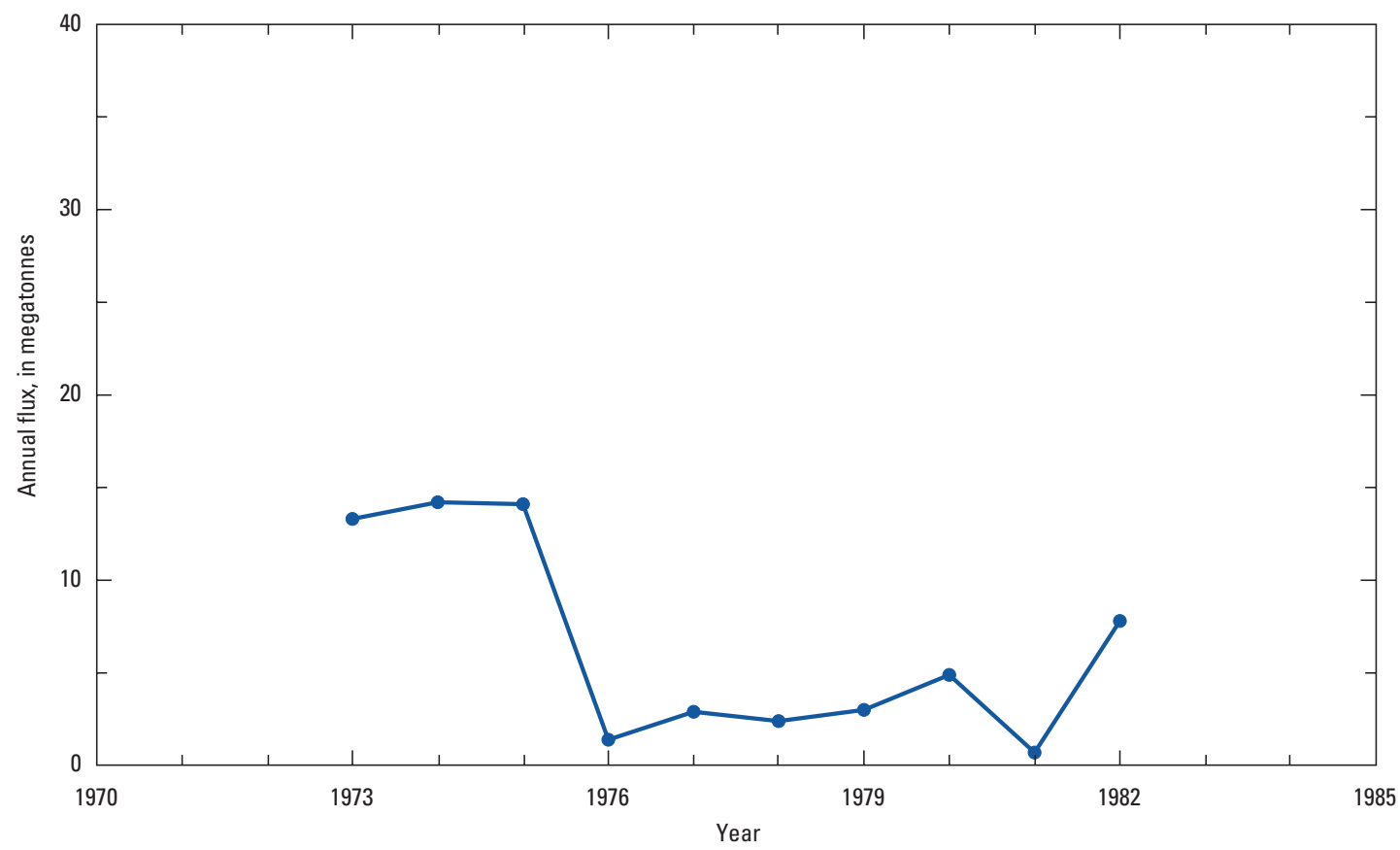

Figure 7. Annual flux estimates for the Arkansas River near Haskell streamflow-gaging station, 1973-82.

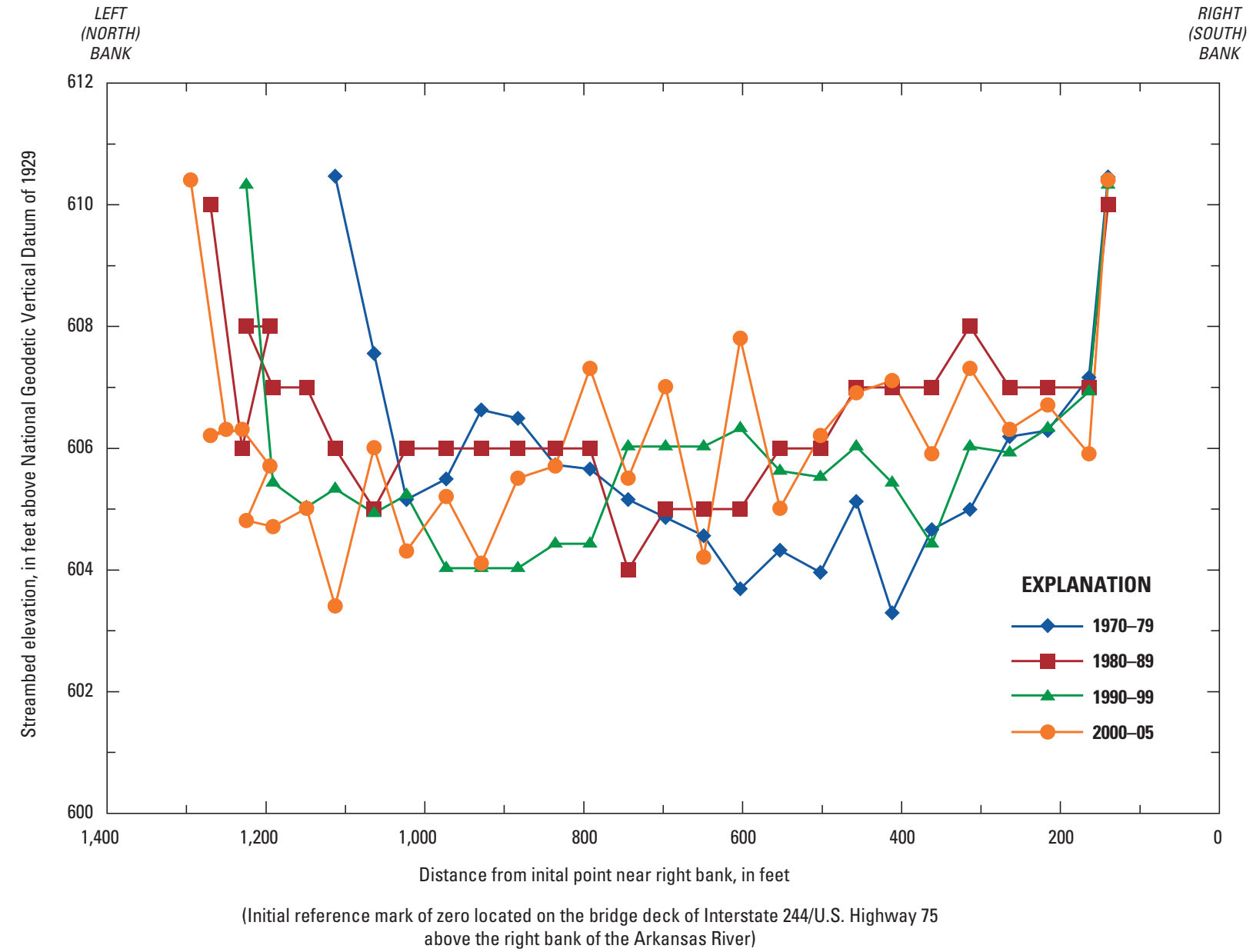

Figure 8. Streambed change over a 35-year period from 1970-2005 at Arkansas River at Tulsa station. 


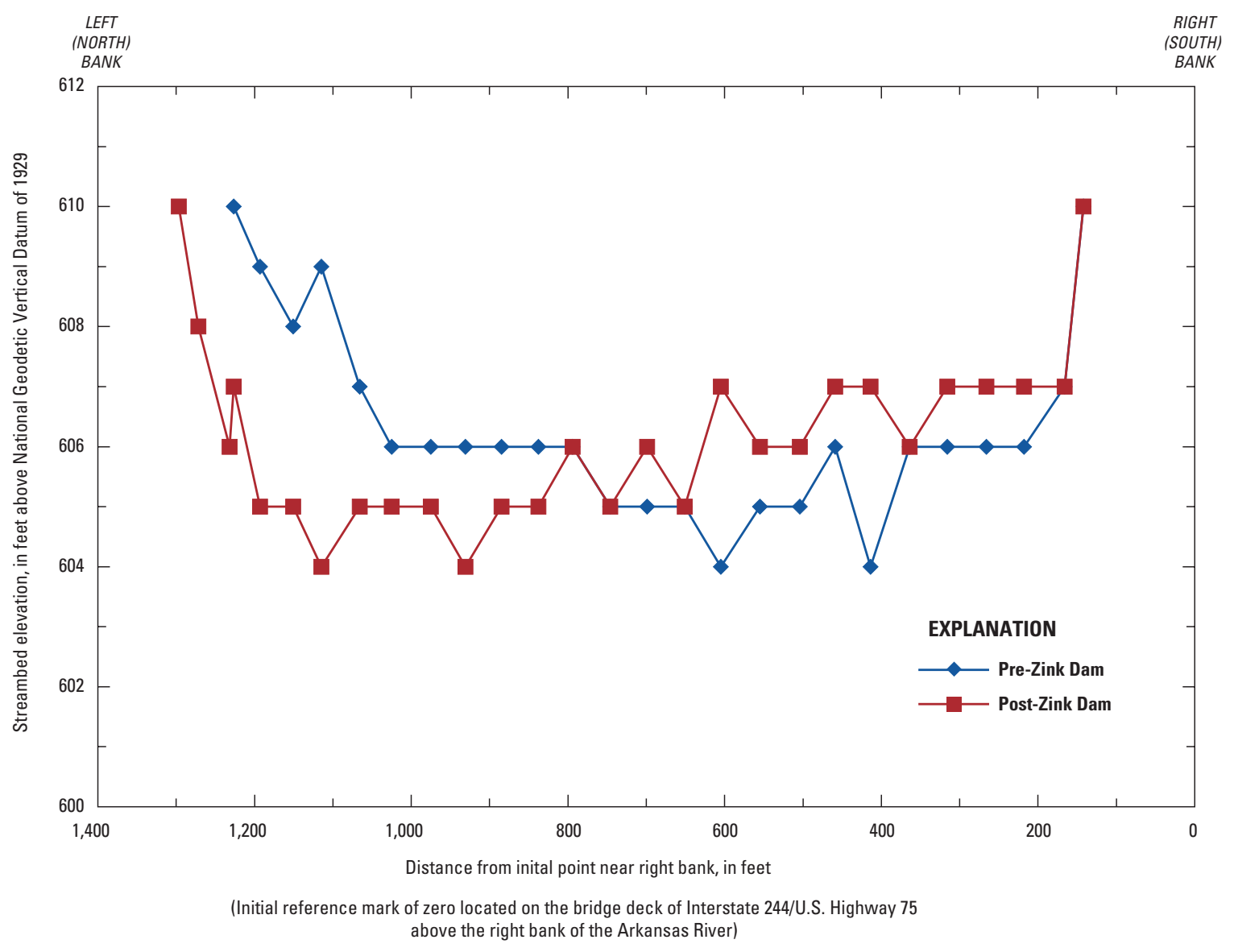

Figure 9. Streambed change before and after the completion of Zink Dam at Arkansas River at Tulsa station.

from Keystone Dam to the Tulsa-Wagoner County line was about 41.1 miles long and was shortened by about 0.64 miles (1.5 percent) over the post-dam periods between 1977 and 2010 (fig. 10, table 4). Individually, each study segment also had a net decrease in centerline length over the post-dam periods between 1977 and 2010 (fig. 10, table 4).

Shortening of channel length was caused by a decrease in the sinuosity of the channel as mid-channel and meander bars, which were considered part of the channel bank, were eroded with time (figs. 3 and 10). In terms of lateral migration rate, the Arkansas River channel within the study reach was most active in the post-dam period 1977-1985 (7.12 feet per year) and least active for the post-dam period 2003-10 (3.90 feet per year) (table 4). The lateral migration rate for the entire study reach and most of the study segments steadily decreased from the post-dam period 1977-85 to the post-dam period 2003-10 that may indicate some stabilization of the regulated channel (fig. 11, table 4) or decreases in the magnitude and frequency of high-discharge tributary flows over time in the post-dam periods have occurred. Channel lateral migration rates computed for the Arkansas River study segments ranged from 3.81 to 8.41 feet per year during the transition period (1950-77) and from 1.73 to 9.08 feet per year during the post-dam periods (1977-85, 1985-2003, and 2003-10; table 4). These rates are less than channel lateral migration rates computed for the Missouri River downstream from Fort Peck Dam, Montana (5.9 to 21.6 feet per year; Shields and others, 2000), and for the Trinity River downstream from Lake Livingston Dam, Texas (9.3 to 16.2 feet per year; Wellmeyer and others, 2005).

Since construction of Keystone Dam, the main inputs of new sediment to the Arkansas River channel likely have been from tributary flows, especially from Polecat Creek and Haikey Creek in study segments "E" and "F," respectively. Tributary inputs of sediment can be substantial, even for smaller tributaries, taking decades to fully erode. However, lack of more recent sediment contribution has resulted in the net removal of meander and mid-channel bar deposits with time since flow regulation began. The rate of disappearance of mid-channel bars is difficult to measure from aerial photography because of changes in river stage and, thus, was not quantified as a part of this study.

The greatest channel narrowing occurred in the transition period 1950-77 and ranged from -11.81 to -3.44 feet per year (fig. 10, table 4). Channel narrowing during the transition period may be a result of degradation and rapid encroachment of vegetation into the channel following completion of Keystone Dam in 1964. Degradation followed by encroachment of vegetation is a typical response of channels to flow 


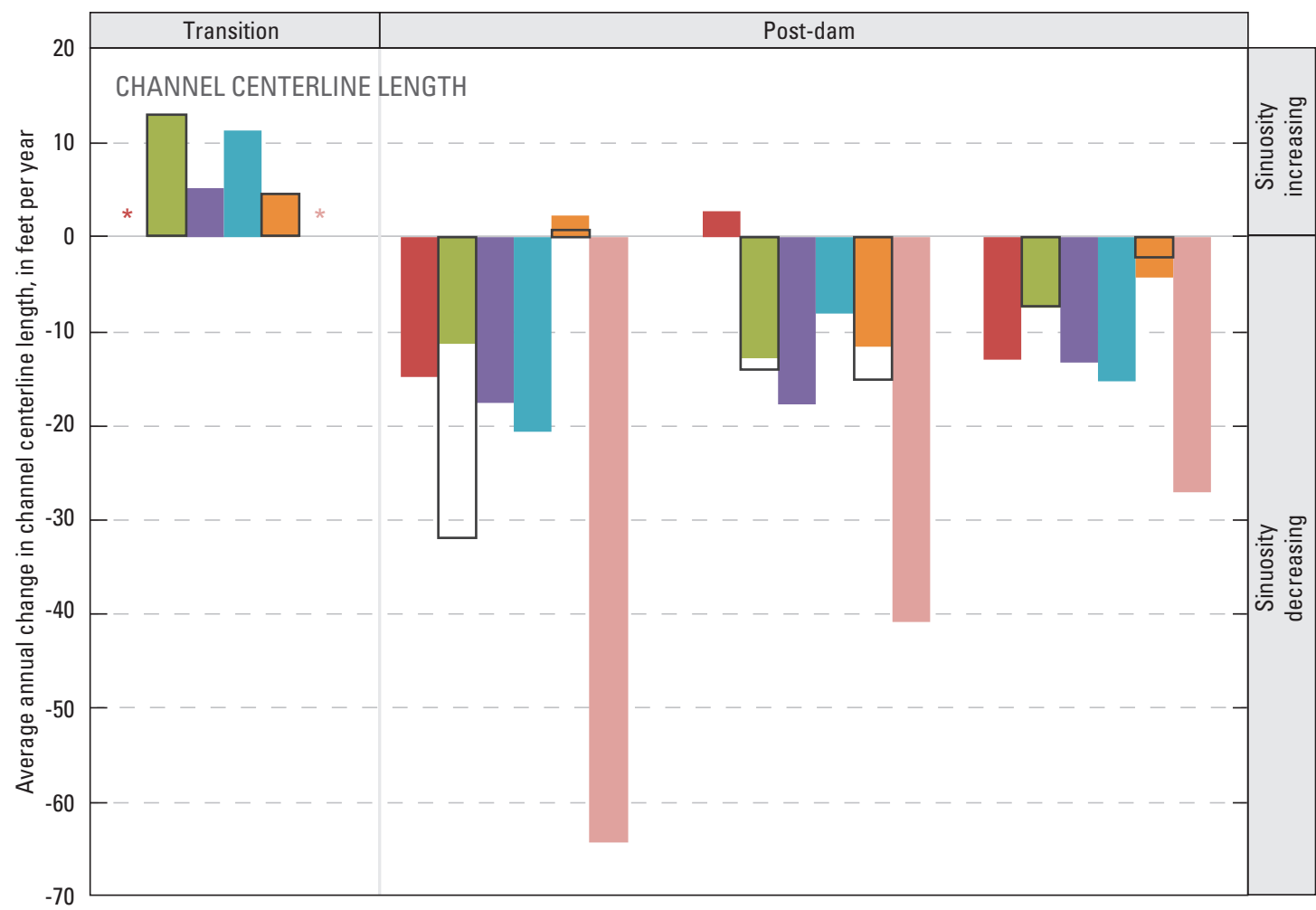

EXPLANATION

Study segment

D

E

F

Black lines around the bars for segments B and $\mathrm{E}$ represent the subsegment covered by 1950 aerial photography.

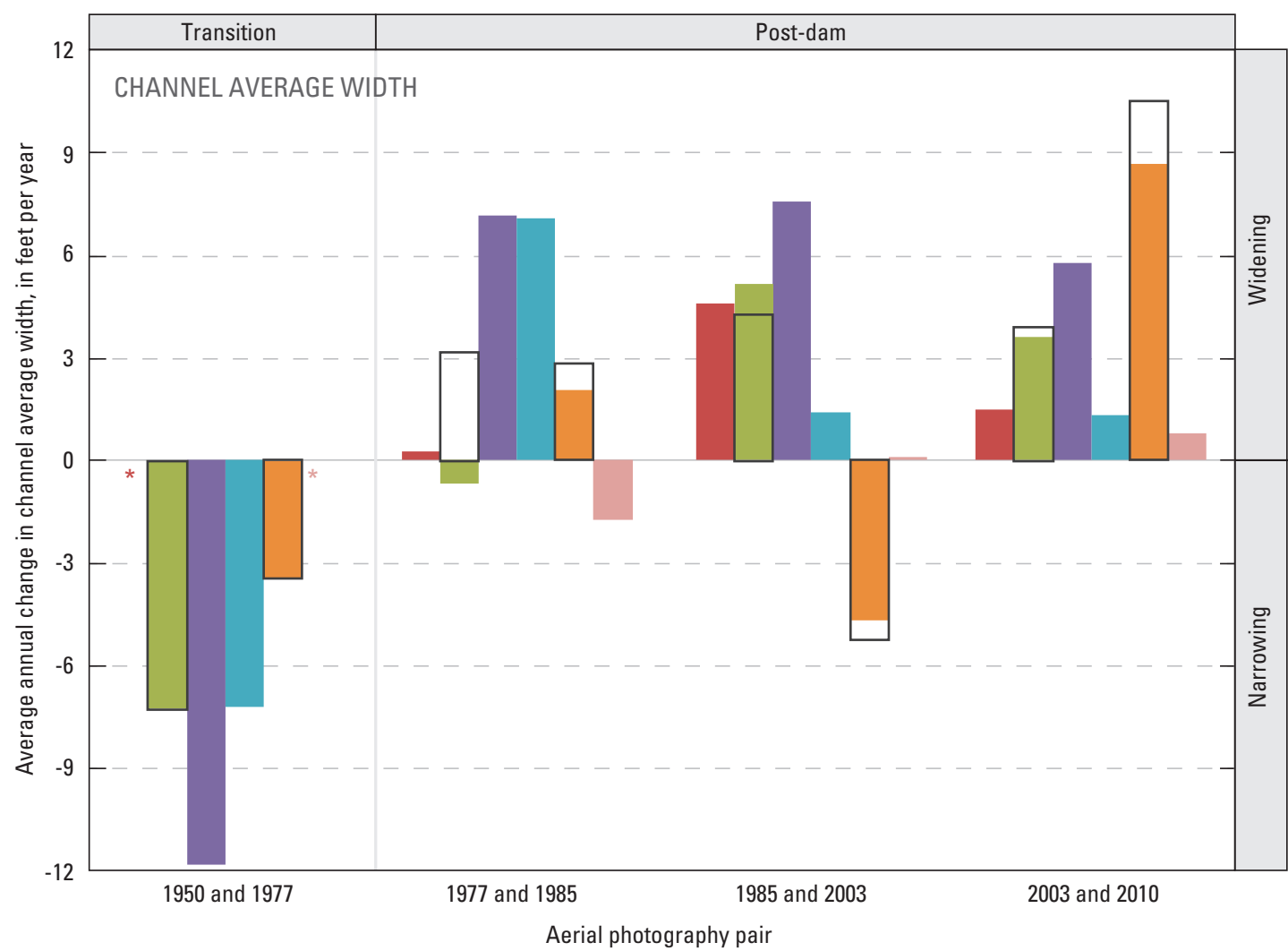

* Aerial photography unavailable for study segments A and F in 1950

Figure 10. Annual change in channel centerline length and channel average width for study segments of the Arkansas River study reach between Keystone Dam and the Tulsa-Wagoner County line, Oklahoma: study segments end at (A) State Highway 97, (B) Interstate 244 / U.S. Highway 75, (C) Interstate 44 / State Highway 66, (D) Creek Turnpike, (E) Memorial Road, and (F) Tulsa-Wagoner County line. 
Table 5. Comparison of estimated annual suspended-sediment fluxes using rating curves for the Arkansas River at Tulsa, Oklahoma, streamflow-gaging station (1931-95).

[Mt; megatonnes, bold numbers; predicted flux selected]

\begin{tabular}{|c|c|c|c|c|c|c|c|c|c|c|c|}
\hline \multirow[b]{2}{*}{$\begin{array}{l}\text { Water } \\
\text { year }\end{array}$} & \multicolumn{2}{|c|}{$\begin{array}{l}\text { Linear } \\
\text { regression }\end{array}$} & \multicolumn{2}{|c|}{$\begin{array}{l}\text { Polynomial } \\
\text { regression }\end{array}$} & \multirow{2}{*}{$\begin{array}{l}\text { Best fit } \\
\text { predicted } \\
\text { flux } \\
\text { (Mt) }\end{array}$} & \multirow[b]{2}{*}{$\begin{array}{l}\text { Water } \\
\text { year }\end{array}$} & \multicolumn{2}{|c|}{$\begin{array}{l}\text { Linear } \\
\text { regression }\end{array}$} & \multicolumn{2}{|c|}{$\begin{array}{l}\text { Polynomial } \\
\text { regression }\end{array}$} & \multirow{2}{*}{$\begin{array}{c}\text { Best fit } \\
\text { predicted } \\
\text { flux } \\
\text { (Mt) }\end{array}$} \\
\hline & $\begin{array}{c}\text { Pre- } \\
\text { dicted } \\
\text { flux } \\
\text { (Mt) }\end{array}$ & $\begin{array}{c}\text { Corrected } \\
\text { predicted } \\
\text { flux } \\
\text { (Mt) }\end{array}$ & $\begin{array}{l}\text { Pre- } \\
\text { dicted } \\
\text { flux } \\
\text { (Mt) }\end{array}$ & $\begin{array}{c}\text { Corrected } \\
\text { predicted } \\
\text { flux } \\
\text { (Mt) }\end{array}$ & & & $\begin{array}{l}\text { Pre- } \\
\text { dicted } \\
\text { flux } \\
\text { (Mt) }\end{array}$ & $\begin{array}{c}\text { Corrected } \\
\text { predicted } \\
\text { flux } \\
\text { (Mt) }\end{array}$ & $\begin{array}{l}\text { Pre- } \\
\text { dicted } \\
\text { flux } \\
\text { (Mt) }\end{array}$ & $\begin{array}{c}\text { Corrected } \\
\text { predicted } \\
\text { flux } \\
\text { (Mt) }\end{array}$ & \\
\hline 1931 & 1.71 & 2.65 & 1.78 & 2.75 & 1.71 & 1965 & 1.19 & 2.88 & 1.56 & 3.86 & 3.86 \\
\hline 1933 & 1.91 & 2.97 & 2.09 & 3.24 & 1.91 & 1967 & .34 & .83 & .33 & .82 & .82 \\
\hline 1934 & .79 & 1.23 & .77 & 1.20 & .79 & 1968 & .43 & 1.03 & .38 & .95 & .95 \\
\hline 1935 & 15.05 & 23.39 & 16.44 & 25.48 & 15.05 & 1969 & 1.12 & 2.70 & 1.20 & 2.96 & 2.96 \\
\hline 1936 & 1.65 & 2.56 & 1.76 & 2.73 & 1.65 & 1970 & .56 & 1.35 & .59 & 1.45 & 1.45 \\
\hline 1940 & 2.33 & 3.62 & 2.47 & 3.83 & 2.33 & 1974 & 2.39 & 5.77 & 3.29 & 8.12 & 8.12 \\
\hline 1941 & 8.33 & 12.94 & 9.20 & 14.26 & 8.33 & 1975 & 2.39 & 5.77 & 3.25 & 8.02 & 8.02 \\
\hline 1942 & 35.59 & 55.30 & 38.14 & 59.12 & 35.59 & 1976 & .32 & .76 & .27 & .66 & .66 \\
\hline 1943 & 18.07 & 28.09 & 17.77 & 27.55 & 18.07 & 1977 & .59 & 1.41 & .61 & 1.51 & 1.51 \\
\hline 1944 & 23.79 & 36.97 & 24.74 & 38.35 & 23.79 & 1978 & .50 & 1.20 & .44 & 1.08 & 1.08 \\
\hline 1945 & 29.05 & 45.15 & 30.04 & 46.56 & 29.05 & 1979 & .73 & 1.77 & .72 & 1.78 & 1.78 \\
\hline 1946 & 11.79 & 18.32 & 11.05 & 17.13 & 11.79 & 1980 & 1.10 & 2.65 & 1.13 & 2.80 & 2.80 \\
\hline 1947 & 21.52 & 33.45 & 21.88 & 33.92 & 21.52 & 1981 & .13 & .31 & .11 & .27 & .27 \\
\hline 1953 & .77 & 1.19 & .72 & 1.11 & .77 & 1987 & 4.27 & 10.31 & 8.87 & 21.9 & 21.9 \\
\hline 1954 & .62 & .97 & .62 & .96 & .62 & 1988 & 1.12 & 2.71 & 1.25 & 3.08 & 3.08 \\
\hline 1955 & 5.68 & 8.82 & 6.41 & 9.94 & 5.68 & 1989 & .87 & 2.10 & .92 & 2.27 & 2.27 \\
\hline 1956 & 4.47 & 6.95 & 4.62 & 7.16 & 4.47 & 1990 & .94 & 2.27 & .97 & 2.41 & 2.41 \\
\hline 1957 & 64.46 & 100.17 & 62.83 & 97.39 & 64.46 & 1991 & .12 & .28 & .10 & .24 & .24 \\
\hline 1958 & 9.63 & 14.96 & 10.85 & 16.81 & 9.63 & 1992 & .73 & 1.77 & .70 & 1.74 & 1.74 \\
\hline 1959 & 8.60 & 13.36 & 9.47 & 14.67 & 8.60 & 1993 & 4.07 & 9.82 & 7.31 & 18.0 & 18.0 \\
\hline 1960 & 47.40 & 73.66 & 42.89 & 66.48 & 47.40 & 1994 & .69 & 1.66 & .81 & 2.01 & 2.01 \\
\hline 1961 & 26.12 & 40.58 & 26.43 & 40.97 & 26.12 & 1995 & 3.03 & 7.32 & 5.09 & 12.6 & 12.6 \\
\hline 1962 & 16.91 & 26.28 & 18.30 & 28.37 & 16.91 & & & & & & \\
\hline 1963 & 2.71 & 4.20 & 2.82 & 4.37 & 2.71 & & & & & & \\
\hline 1964 & 1.35 & 2.10 & 1.36 & 2.11 & 1.35 & & & & & & \\
\hline
\end{tabular}


Table 6. Comparison of estimated annual suspended-sediment fluxes using rating curves for the Arkansas River near Haskell streamflow-gaging station (1973-82).

[Mt; megatonnes, bold numbers; predicted flux selected]

\begin{tabular}{|c|c|c|c|c|c|c|c|c|c|c|c|}
\hline \multirow[b]{2}{*}{$\begin{array}{l}\text { Water } \\
\text { year }\end{array}$} & \multicolumn{2}{|c|}{$\begin{array}{l}\text { Linear } \\
\text { regression }\end{array}$} & \multicolumn{2}{|c|}{$\begin{array}{l}\text { Polynomial } \\
\text { regression }\end{array}$} & \multirow{2}{*}{$\begin{array}{l}\text { Best fit } \\
\text { predicted } \\
\text { flux } \\
\text { (Mt) }\end{array}$} & \multirow[b]{2}{*}{$\begin{array}{l}\text { Water } \\
\text { year }\end{array}$} & \multicolumn{2}{|c|}{$\begin{array}{l}\text { Linear } \\
\text { regression }\end{array}$} & \multicolumn{2}{|c|}{$\begin{array}{l}\text { Polynomial } \\
\text { regression }\end{array}$} & \multirow{2}{*}{$\begin{array}{l}\text { Best fit } \\
\text { predicted } \\
\quad \text { flux } \\
\text { (Mt) }\end{array}$} \\
\hline & $\begin{array}{l}\text { Pre- } \\
\text { dicted } \\
\text { flux } \\
\text { (Mt) }\end{array}$ & $\begin{array}{l}\text { Corrected } \\
\text { predicted } \\
\text { flux } \\
\text { (Mt) }\end{array}$ & $\begin{array}{c}\text { Pre- } \\
\text { dicted } \\
\text { flux } \\
\text { (Mt) }\end{array}$ & $\begin{array}{c}\text { Corrected } \\
\text { predicted } \\
\text { flux } \\
\text { (Mt) }\end{array}$ & & & $\begin{array}{c}\text { Pre- } \\
\text { dicted } \\
\text { flux } \\
\text { (Mt) }\end{array}$ & $\begin{array}{l}\text { Corrected } \\
\text { predicted } \\
\text { flux } \\
\text { (Mt) }\end{array}$ & $\begin{array}{l}\text { Pre- } \\
\text { dicted } \\
\text { flux } \\
\text { (Mt) }\end{array}$ & $\begin{array}{l}\text { Corrected } \\
\text { predicted } \\
\text { flux } \\
\text { (Mt) }\end{array}$ & \\
\hline 1973 & 5.4 & 13.3 & 9.4 & 21.9 & 13.3 & 1978 & 1.0 & 2.4 & 0.8 & 1.9 & 2.4 \\
\hline 1974 & 5.8 & 14.2 & 9.5 & 22.2 & 14.2 & 1979 & 1.2 & 3.0 & 1.1 & 2.6 & 3.0 \\
\hline 1975 & 5.8 & 14.1 & 9.2 & 21.4 & 14.1 & 1980 & 2.0 & 4.9 & 2.0 & 4.8 & 4.9 \\
\hline 1976 & .6 & 1.4 & .4 & 1.0 & 1.4 & 1981 & .3 & .7 & .2 & .5 & .7 \\
\hline 1977 & 1.2 & 2.9 & 1.2 & 2.8 & 2.9 & 1982 & 3.2 & 7.8 & 4.2 & 9.8 & 7.8 \\
\hline
\end{tabular}

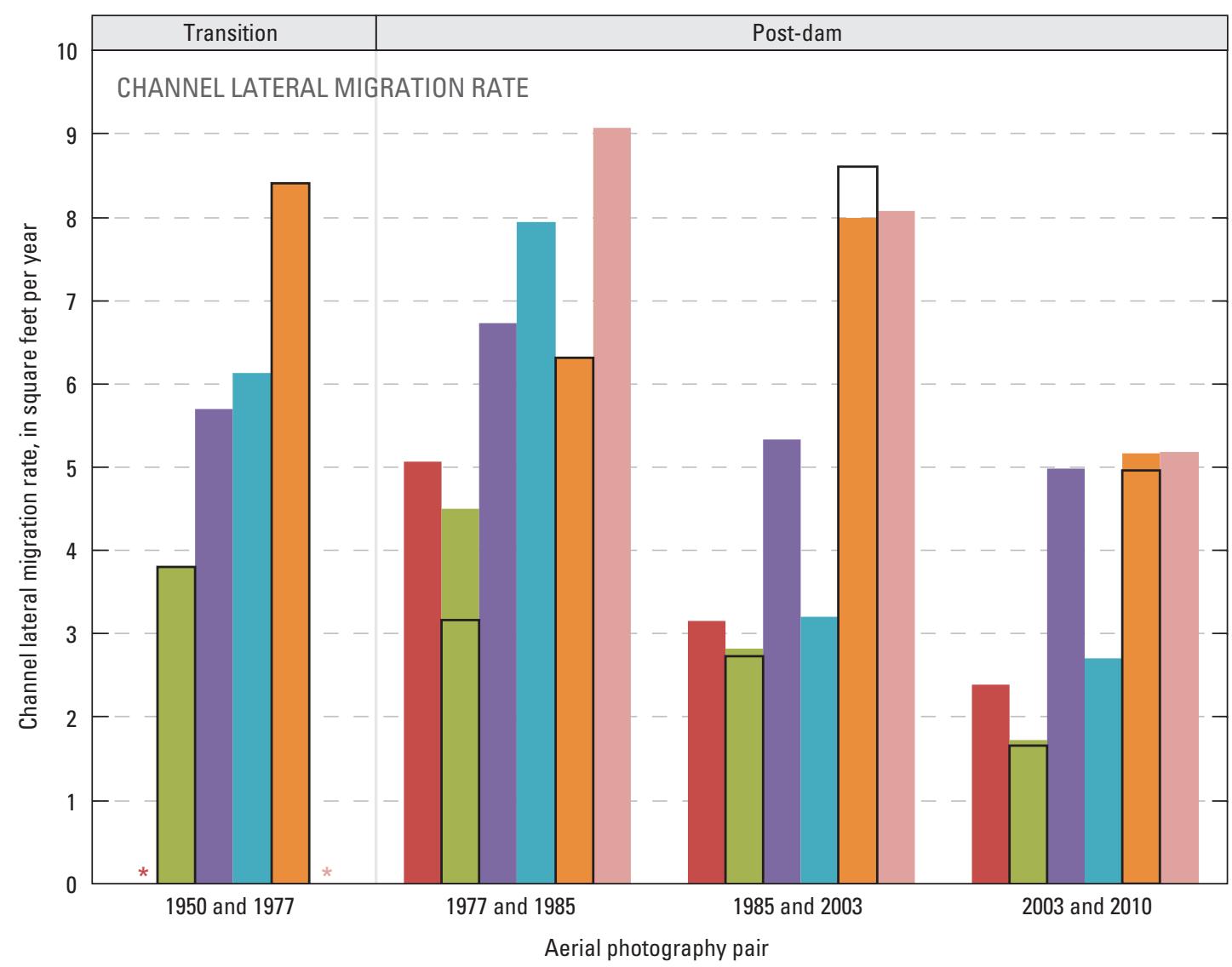

\section{EXPLANATION}

Study segment A B C C D

$E$ $\mathrm{F}$

Black lines around the bars for segments B and $E$ represent the subsegment covered by 1950 aerial photography.

* Aerial photography unavailable for study segments $A$ and $F$ in 1950

Figure 11. Channel lateral migration rate (Shields and others, 2000) for study segments of the Arkansas River study reach between Keystone Dam and the Tulsa-Wagoner County line, Oklahoma: study segments end at (A) State Highway 97, (B) Interstate 244 / U.S. Highway 75, (C) Interstate 44 / State Highway 66, (D) Creek Turnpike, (E) Memorial Road, and (F) Tulsa-Wagoner County line. 
regulation by dams (Williams and Wolman, 1984). Most of the study segments widened over the post-dam periods (fig. 10, table 4). Only the two most downstream segments (E and F) had channel narrowing at an average rate greater than 1 foot per year for the post-dam periods (fig. 10, table 4). Segment "E" narrowed at an average rate of about 5 feet per year over the post-dam period 1985-2003 (fig. 10, table 4). This narrowing was followed by substantial channel widening $(8.67-10.51$ feet per year) in segment "E" from 2003-10 (table 4). Changes in average channel width for segment "E" probably were caused by changes in sediment storage at and just downstream from the Polecat Creek confluence (fig. 3). Polecat Creek, in terms of drainage basin area, is the largest tributary that joins the Arkansas River in the study reach (fig. 2). Most of the channel segments showed some channel widening over the post-dam periods (fig. 10). With the exception of the 2003-10 widening in segment " $\mathrm{E}$," the greatest channel widening $(7.56 \mathrm{ft} / \mathrm{yr})$ occurred in segment "C" over the post-dam period 1985-2003 (fig. 10, table 4).

\section{Summary and Conclusions}

This report presents the results of a cooperative study by the U.S. Geological Survey (USGS) and Tulsa County to estimate annual suspended-sediment fluxes and to evaluate geomorphologic changes of the Arkansas River in Tulsa County, Oklahoma. Annual suspended-sediment fluxes were estimated from 1931-95 for the Arkansas River at Tulsa, Oklahoma, streamflow-gaging station and from 1973-82 for the Arkansas River near Haskell, Oklahoma, streamflow-gaging station. Completion of Keystone Dam in 1964 reduced the mean annual suspended-sediment concentration by 82 percent from 1,970 milligrams per liter (1931-64) to 350 milligrams per liter (1965-95). The mean annual suspended-sediment flux at the Tulsa station before completion of Keystone Dam was 14.7 megatonnes and 4.0 megatonnes after completion. The mean annual flux for Haskell station was 6.5 megatonnes. During the same period (1973-82) both stations had similar patterns in annual fluxes, with the Haskell station always having a greater annual flux.

By analyzing the depths from discharge measurements of the same stage and discharge over time, the streambed elevations were shown to have no major change (less than 1.0 foot) from the period of 1970-2005. The thalweg shifted from a position near the right bank to a position located closer to the left bank.

There was little change in the position of most of the banks of the Arkansas River channel from 1950 to 2010 as defined using morphological metrics. The biggest change evident from visual inspection of aerial photography was an apparent decrease in sediment storage in the form of midchannel and meander bars. Since construction of Keystone Dam, the main inputs of new sediment to the Arkansas River channel likely have been from tributary flows, especially from
Polecat Creek and Haikey Creek in study segments "E" and "F," respectively. Tributary inputs of sediment can be substantial, even for smaller tributaries, taking decades to fully erode. However, lack of more recent sediment contribution has resulted in the net removal of meander and mid-channel bar deposits with time since flow regulation began. The rate of disappearance of mid-channel bars is difficult to measure from aerial photography because of changes in river stage and, thus, was not quantified as a part of this study.

Generally, the Arkansas River channel between Keystone Dam and the Tulsa-Wagoner County line showed a narrowing and lengthening (increase in sinuosity) over the transition period 1950-77 followed by a steady widening and shortening (decrease in sinuosity) over the post-dam periods 1977-85, 1985-2003, and 2003-10. The most recent period (2003-10) had the smallest amount of average annual change in centerline length and channel width, with a relatively small amount of centerline shortening and channel widening. That smaller change may be a result of channel stabilization or a decrease in the frequency of high discharge tributary flows over the post-dam period 2003-10.

Because of the urban setting of much of the Arkansas River study reach, many of the channel banks have been lined with rip-rap for erosion control. The effectiveness of these and other erosion control structures was not analyzed as part of this study. However, it is likely that these structures affect the rate of erosion and migration of channel banks over most of the study segments.

\section{References Cited}

Carter and Burgess Inc., 2004, Final Arkansas River corridor master plan: Phase I vision plan: Prepared for Indian Nations Council of Governments, Tulsa, Oklahoma, August 2004.

Copeland, R.R., Biednharn, D.S., and Fischenich, J.C., 2000, Channel-forming discharge: U.S. Army Corps of Engineers ERDC/CHL CHETN-VIII-5, $10 \mathrm{p}$.

Duan, N., 1983, Smearing estimate - a nonparametric retransformation method: Journal of the American Statistical Association, v. 78, no. 383, p. 605-610.

ESRI, 2010, Collapse dual lines to centerline (data management): ArcGIS Desktop Help, accessed on February 12, 2011, at http://webhelp.esri.com/arcgiSDEsktop/9.2/index. cfm?TopicName=collapse_dual_lines_to_centerline_(data_ management.

Guernsey, C.H., and Company, Edaw Inc., Hisinc, LLC, Alaback Design and Associates, Adaptive Ecosystems, Inc., Schnake Turnbo Frank, Inc., 2005, Final Arkansas River corridor master plan, Phase II master plan and prereconnaissance study: Prepared for the U.S. Army Corps of Engineers. 
Helsel, D.R., and Hirsch, R.M., 2002, Statistical methods in water research: Amsterdam, Elsevier, 529 p.

Horowitz, A.J., 2008, Determining annual suspended sediment and sediment-associated trace element and nutrient fluxes: The Science of the Total Environment, v. 400, p. 315-343.

Horowitz, A.J., 2003, An evaluation of rating curves for estimating suspended sediment concentrations for subsequent flux calculations: Hydrological Processes, v. 17, p. $3,387-3,409$.

Horowitz, A.J., Elrick, K.A., and Smith, J.J., 2001, Estimating suspended sediment and trace element fuxes in large river basins: Methodological considerations as applied to the NASQAN Program: Hydrological Processes, v. 15, p. 1,107-1,132.

Juracek, K.E., 1999, Geomorphic effects of overflow dams on the Neosho River, Kansas: U.S. Geological Survey WaterResources Investigations Report 99-4147, 6 p.

Leslie, D.M., Wood, G.K., and Carter, T.S., 2000, Productivity of endangered least terns (Sterna antillarum athalassos) below a hydropower and flood-control facility on the Arkansas River: The Southwestern Naturalist, v. 45, no. 4, p. 483-489, accessed on December 2, 2010, at http://www. jstor.org/stable/3672597.

Lewis, J.M., and Esralew, R.A., 2009, Statistical summaries of streamflow in and near Oklahoma through 2007: U.S. Geological Survey Scientific Investigations Report 20065112, 152 p.

Pickup, G., and Warner, R.F., 1976, Effects of hydrologic regime on magnitude and frequency of dominant discharge: Journal of Hydrology, v. 29, p. 51-75, accessed on January 11, 2011, at (http://www.sciencedirect.com/science/article/ B6V6C-487F8T2-4T/2/ccbcce3b2d3c889d39d07a1fdc5b c4e7).

Porterfield, G., 1977, Computation of fluvial-sediment discharge: U.S. Geological Survey Techniques of WaterResources Investigations, book 3, chap. C3, 66 p.
Shields, F.D., Simon, A., Steffen, L.J., 2000, Reservoir effects on downstream river channel migration: Environmental Conservation, v. 27, p. 54-66.

State of Oklahoma, 2003, Digital orthophotography: Oklahoma Geographic Information Council, accessed May 25, 2011, at http://okmaps.onenet.net/GIS_data.htm.

State of Oklahoma, 2006, Digital orthophotography: Oklahoma Geographic Information Council, accessed May 25, 2011, at http://okmaps.onenet.net/GIS_data.htm.

State of Oklahoma, 2008, Digital orthophotography: Oklahoma Geographic Information Council, accessed May 25, 2011, at http://okmaps.onenet.net/GIS_data.htm.

U.S. Geological Survey, 2010, USGS water data for the Nation: U.S. Geological Survey National Water Information System: Web Interface, accessed December 2, 2010, at http://waterdata.usgs.gov/nwis/.

U.S. Geological Survey, 2006, Collection of water samples (ver. 2.0): U.S. Geological Survey Techniques of WaterResources Investigations, book 9, chap. A4, September, accessed February 2, 2011, at http://pubs.water.usgs.gov/ twri9A4/.

VanLooy, J.A., and Martin, C.W., 2005, Channel and vegetation change on the Cimarron River, southwestern Kansas, 1953-2001: Annals of the Association of American Geographers, v. 95, p. 727-739.

Wellmeyer, J.L., Slattery, M.C., and Phillips, J.D., 2005, Quantifying downstream impacts of impoundment of flow regime and channel planform, lower Trinity River, Texas: Geomorphology, v. 69, p. 1-13.

Williams, G.P., 1978, Bankfull discharge of rivers: Water Resources Research, v. 14, no. 6, p. 1,141-1,154.

Williams, G.P., and Wolman, M.G., 1984, Downstream effects of dams on alluvial rivers: U.S. Geological Survey Professional Paper 1286, 83 p.

For more information concerning this publication, contact: Director, USGS Oklahoma Water Science Center 202 NW 66th St., BIdg. 7 Oklahoma City, OK 73116

(405) $810-4400$

Or visit the Oklahoma Water Science Center Web site at: http://ok.water.usgs.gov 
